ROJAS, Luis Emilio. "Modelos de regulación de los delitos de falsedad y de los delitos patrimoniales".

Polít. crim. Vol. 12, № 23 (Julio 2017), Art. 10, pp. 380-408.

[http://www.politicacriminal.cl/Vol_12/n_23/Vol12N23A10.pdf]

\title{
Modelos de regulación de los delitos de falsedad y de los delitos patrimoniales
}

\section{Regulatory models in falsehood and patrimonial crimes}

\author{
Luis Emilio Rojas A.* \\ Dr. iur. Albert-Ludwigs-Universität Freiburg (LL.M.), \\ Profesor de Derecho penal \\ Facultad de Derecho Universidad Alberto Hurtado \\ lurojas@uahurtado.cl
}

\section{Resumen}

La legislación penal vigente en materia de falsedades y de delitos patrimoniales se encuentra manifiestamente desfasada. El presente trabajo aborda este ámbito de la parte especial desde una perspectiva de técnica legislativa. Junto con someter a crítica la legislación vigente, se comentan también críticamente las propuestas formuladas recientemente en los Anteproyectos y en el Proyecto de nuevo Código penal chileno. Este crítica se emprende en aplicación del concepto de tipo modelo, acuñado por Joachim Vogel, y revisando los modelos de regulación de la materia que pueden extraerse del Código penal español de 1995, incluida su última reforma en 2015, y del Código penal alemán.

Palabras clave: Falsedades, delitos patrimoniales, legislación penal, tipos modelo.

\section{Zusammenfassung}

Die bestehende Strafgesetzgebung der Fälschungs- und Vermögensdelikte ist offenbar nicht mehr zeitgemäss. Der vorliegende Beitrag behandelt dieses Gebiet des Besonderen Teils aus der Sicht der Strafgesetzgebungstechnik. Nebst der Kritik der bestehenden Strafgesetzgebung analisiert der Beitrag ebenso in kritischer Hinsicht die jüngsten Vorentwürfe und der vor kurzem vefasste Entwurf eines neuen Strafgesetzbuches. Diese Kritik wird anhand des von Joachim Vogel vorgeschlagenen Begriffs des „Tatbestandsmodells“ unternommen und anhand der dem spanischen Strafgesetzbuch aus dem Jahre 1995, einschliesslich der jüngsten Reform aus dem Jahre 2015, und dem deutschen Strafgesetzbuch zugrunde liegenden Regelungsmodelle dieser Delikte bearbeitet.

Stichworte: Fälschungsdelikte, Vermögensdelikte, Strafgesetzgebung, Tatbestandsmodelle.

\footnotetext{
* Este trabajo se basa en una ponencia del mismo título presentada en el seminario organizado por el Centro de Estudios de Derecho penal y procesal penal Latinoamericano de la Universität Göttingen el 31 de marzo y el $1^{\circ}$ de abril de 2015 , sobre la reforma penal en Chile.
} 


\section{ROJAS, Luis Emilio. "Modelos de regulación de los delitos de} falsedad y de los delitos patrimoniales".

\section{Introducción.}

La relación entre los delitos de falsedad y los delitos de carácter patrimonial es de antigua data. Se remonta históricamente al Derecho penal romano, en cuyo origen se encuentra la lex Cornelia testamentaria nummaria del año 81 a.C., que castigaba con la misma pena la falsificación de testamentos y la de monedas ${ }^{1}$. Posteriormente, esta misma lex, mediante una serie de Senadoconsultos, abarcó otras falsedades documentales e incluso a partir del siglo III, por medio de la jurisprudencia, llegó a extenderse al estelionato, aunque éste en un carácter subsidiario y con una pena más leve ${ }^{2}$. Este vínculo histórico permite explicar que Paul Johann Anselm Feuerbach, en su obra sobre el Derecho penal común vigente en Alemania a principios del siglo XIX, tratase todavía conjuntamente la falsedad y la estafa ${ }^{3}$. El deslinde se produjo recién durante ese siglo con el proceso de codificación, mediante el cual se separaron sistemáticamente, por una parte, las falsificaciones de diversa índole normalmente bajo el acápite de los delitos contra la fe pública y, por otra, los delitos en perjuicio de los derechos patrimoniales de otra persona ${ }^{4}$. El Código penal chileno de 1874 (en adelante, $\mathrm{CPCh}$ ), aún vigente, siguió esta regulación sistemática.

A continuación, se somete a valoración crítica la técnica legislativa adoptada por el Código penal en la regulación de los delitos de falsificación de monedas y otros medios de pago (arts. 162 y ss.), de las falsedades documentales y de certificados (arts. 193 y ss.), así como de la forma de tipificar las falsificaciones de tarjetas de pago en la Ley 20.009, de 2005. Asimismo, se critica la regulación vigente de los delitos patrimoniales (arts. 467 y ss. $\mathrm{CPCh}$ ). Dado que el ámbito temático así delimitado es bastante amplio, es menester poner acento en ciertas figuras delictivas, cuya regulación en la legislación penal vigente es particularmente desacertada. Se trata de la regulación, por un lado, de la falsificación de monedas y de otros medios de pago, de las falsedades documentales, y, por el otro, de las estafas, así como de sus relaciones intrasistemáticas. Para emprender esta parte del análisis crítico, se recurre a criterios básicos de una técnica moderna de legislación penal.

Luego, en un acápite comparativo, se estudia la regulación sistemática de ambos grupos de delitos en el Código penal español de 1995 (arts. 248 y ss., arts. 386 y ss.; en adelante, CPE) y en el Strafgesetzbuch ( $\S 146$ ff., $\S 263$ ff.; en lo sucesivo, StGB). Asimismo, se comenta críticamente tanto la propuesta de regulación de estos delitos contenida en el Anteproyecto de Código penal chileno de diciembre de 2005 (arts. 159 y ss., arts. 234 y ss.; en adelante, ACP 2005) como la incluida en el Proyecto de nuevo Código penal presentado en el Congreso Nacional en marzo de 2014 (arts. 330 y ss., arts. 395 y ss.; en lo sucesivo, PCP 2014). Finalmente, se incluye un breve comentario al Anteproyecto de 2015 (arts. 293 y ss., arts. 357 y ss., en adelante ACP 2015).

\footnotetext{
${ }^{1}$ MOMMSEN, Theodor, Römisches Strafrecht, Leipzig: Duncker \& Humblot, 1899, pp. 669 y ss.; D’ORS, Álvaro, "Contribuciones a la historia del "crimen falsi"”, en: VV.AA., Studi in onore di Edoardo Volterra, Milán: Giuffrè, Vol. II, 1969, p. 545 y s.

2 MOMMSEN, Römisches, cit. nota n 1, pp. 678 y ss.; D’ORS, “Contribuciones”, cit. nota n 1 , p. 557 y s.

${ }^{3}$ FEUERBACH, Paul Johann Anselm, Lehrbuch des gemeinen in Deutschland gültigen peinlichen Rechts, Aalen: Scientia Verlag, 1986, (1847), § 410 y ss.

${ }^{4}$ JAKOBS, Günther, Urkundenfälschung, Köln: Carl Heymanns Verlag, 2000, pp. 1 y ss., pp. 5 y ss.
} 
Polít. crim. Vol. 12, No 23 (Julio 2017), Art. 10, pp. 380-408.

[http://www.politicacriminal.cl/Vol_12/n_23/Vol12N23A10.pdf]

Esta segunda parte del estudio se emprende con la pretensión de buscar modelos de regulación para ambos grupos de delitos. Por modelo de regulación se entiende "una regulación típica ideal de un estado de hecho típico, que es lógica, sistemática y teleológicamente coherente" ". El estado fáctico típico, que pertenece a un modelo de regulación, se denomina ámbito regulativo. En términos dogmáticos, los modelos de regulación contienen tipos modelo que, a diferencia de los tipos del Derecho positivo frecuentemente incompletos, no evidencian inconsistencias lógicas, sistemáticas o teleológicas ${ }^{6}$.

Dicho concepto fue acuñado por Joachim Vogel como alternativa a la teoría del bien jurídico y también a la dogmática de los tipos delictivos, frente a la limitación que evidencian estas formas tradicionales de abordar críticamente la legislación penal vigente. El potencial crítico de estas dos perspectivas es muy limitado, porque, por un lado, la primera sirve básicamente para determinar el objeto de protección de la norma y aquel sobre el cual recae la realización de la conducta y, por el otro, la segunda esclarece solamente la forma de ataque al bien jurídico ${ }^{7}$. Pero, ambas perspectivas en conjunto soslayan aspectos relevantes en el análisis, tales como determinadas calidades del autor, v.gr.: los deberes especiales a los cuales se encuentra sujeto, y circunstancias fácticas especiales definitorias del hecho punible. Un análisis del tipo, en cambio, que se emprenda desde los modelos de regulación, permite incluir al conjunto de todos los elementos del tipo. Al aplicar este método, puede quedar en evidencia que un tipo determinado de la legislación penal vigente, como por ejemplo el § 299 StGB a la sazón analizado por Vogel, se basa en varios modelos de regulación, incluso contradictorios entre sí, dando origen a un "tipo híbrido". La función del método es, entonces, solamente poner en evidencia estas contradicciones internas, proceder que parece ser más honesto que constreñir, mediante una valoración desde el bien jurídico, a una interpretación unificadora de un tipo en sí contradictorio $^{8}$.

\section{Valoración crítica de la legislación penal vigente en materia de falsedades y de delitos patrimoniales.}

\subsection{Regulación de la falsificación de dinero.}

La regulación vigente de los delitos de falsificación de dinero, medios de pago y otros títulos es muy engorrosa, casuística y asistemática. Se divide en tres secciones, todas agrupadas bajo el título IV de los crímenes y simples delitos contra la fe pública. La primera sección se refiere a la moneda falsa (arts. 162 - 171), la segunda abarca la falsificación de títulos como los bonos del Estado, cupones de intereses, obligaciones al portador de la deuda pública de país extranjero, acciones o promesas de acciones de

\footnotetext{
${ }^{5}$ El adjetivo típico se usa, en relación al substantivo regulación, en el sentido de la categoría del tipo, y respecto del estado de hecho o ámbito fáctico ("Sachverhalt") en el sentido de habitual o característico.

${ }^{6}$ VOGEL, Joachim, "Wirtschaftskorruption und Strafrecht - Ein Beitrag zu Regelungsmodellen im Wirtschaftsstrafrecht -", en: HEINRICH, Bernd; HILGENDORF, Eric; MITSCH, Wolfgang; STERNBERGLIEBEN, Detlev (editores), Festschrift für Ulrich Weber zum 70. Geburtstag, Bielefeld: Verlag Ernst und Werner Gieseking, 2004, p. 398.

${ }^{7}$ VOGEL, "Wirtschaftskorruption", cit. nota n ${ }^{\circ} 6$, p. 398 y s.

${ }^{8}$ VOGEL, "Wirtschaftskorruption", cit. nota n ${ }^{\circ}$ 6, p. 399 y s.
} 
ROJAS, Luis Emilio. "Modelos de regulación de los delitos de falsedad y de los delitos patrimoniales".

sociedades anónimas y otros (arts. 172 - 179) y la tercera parte se refiere a la falsificación de sellos del Estado, punzones, cuños o instrumentos para la fabricación de monedas, estampillas, boletas de transporte o de espectáculos públicos y de otros objetos equivalentes (arts. 180 - 192 CPCh). Ya esta larga enumeración solamente de las secciones muestra que la regulación vigente es innecesariamente casuística y engorrosa.

Desde el punto de vista de la técnica legislativa, esto es, en una perspectiva netamente formal, la regulación vigente contraviene un criterio básico de economía legislativa, que exige precisión y ser conciso tanto en el número de preceptos como en la descripción de la materia abarcada por cada uno ${ }^{9}$. Este principio de economía legislativa no es un fin en sí mismo, sino que es funcional a la capacidad comunicativa de las normas y funge como corolario del principio de legalidad, ya que una regulación legislativa farragosa dificulta tanto al profano como al técnico del Derecho determinar el alcance de cada prohibición ${ }^{10}$. Pues bien, la actual regulación de la materia violenta este principio en sus dos componentes. Primero, porque la regula en treinta (30) artículos, divididos en tres partes según la clase de objeto sobre el que recae la conducta de falsificación. Es decir, el criterio de clasificación de los tipos radica en la clase de objeto material y así, por ejemplo, se llega a distinguir entre una moneda de oro o plata y una "moneda de vellón" en el art. 163 o entre un bono emitido por el Estado y una obligación al portador de la deuda pública de un país extranjero en los arts. 172 y $173 \mathrm{CPCh}$. Por consiguiente, el criterio determinante para el legislador del siglo XIX, a fin de diferenciar los tipos penales, consiste en la clase de objeto material. Este criterio era comprensible en una época en que el oro jugaba un papel determinante para la economía nacional, pero ha quedado completamente desfasado frente al proceso creciente de desmaterialización del dinero, característico de la economía moderna.

Este último aspecto se relaciona con otro defecto de la legislación vigente, cual es, su carácter asistemático. El tipo de falsificación de billetes se encuentra contemplado en otra ley fuera del Código penal, esto es, en el art. 64 de la Ley N. 18.840, orgánica constitucional del Banco Central. A pesar de que esta misma ley, en sus arts. 30 y 31, reconoce expresamente que tanto los billetes como las monedas cumplen la misma función de ser un medio de pago con poder liberatorio y de circulación ilimitada. Pues bien, la sistematicidad es otro criterio fundamental de una técnica legislativa y abarca tanto una dimensión interna, esto es, al interior del propio ordenamiento normativo penal, como una externa, vale decir, en relación a otras ramas del ordenamiento jurídico ${ }^{11}$. Si los billetes y las monedas cumplen la misma función, entonces resulta asistemático que la legislación penal contemple dos tipos separados y, además, ubicados en cuerpos legislativos distintos. La moneda y el billete son dos formas de expresión de la misma institución del dinero ${ }^{12}$. Lo relevante no es la falsificación de la moneda ni del billete en sí, sino que la falsificación del

\footnotetext{
${ }^{9}$ OSSANDÓN, Magdalena, La formulación de tipos penales. Valoración crítica de los instrumentos de técnica legislativa, Santiago: Editorial Jurídica de Chile, 2009, pp. 303 y ss.

${ }^{10}$ OSSANDÓN, La formulación de los tipos penales, cit. nota n ${ }^{\circ}$ 9, p. 304.

${ }^{11}$ OSSANDÓN, La formulación de los tipos penales, cit. nota n ${ }^{\circ} 9$, pp. 313 y ss.

${ }^{12}$ Cfr. KÖHLER, Michael: "Humes Dilemma - oder: Was ist Geld? ,Geldschöpfung' der Banken als Vermögensrechtsverletzung”, en: FREUND, Georg; MURMANN, Uwe; BLOY, René; PERRON, Walter (editores), Grundlagen und Dogmatik des gesamten Strafrechtssystems. Festschrift für Wolfgang Frisch zum 70. Geburtstag, Berlin: Duncker \& Humblot, 2013, pp. 891 y ss., sobre las funciones del dinero.
} 
Polít. crim. Vol. 12, No 23 (Julio 2017), Art. 10, pp. 380-408.

[http://www.politicacriminal.cl/Vol_12/n_23/Vol12N23A10.pdf]

dinero, puesto que solamente esta forma de ataque puede potencialmente entorpecer el cumplimiento de las funciones que éste cumple en la economía. La falsificación de monedas y la falsificación de billetes pertenecen al mismo ámbito fáctico regulativo, el cual, en consecuencia, debería encontrarse descrito más bien en un mismo tipo modelo.

El mencionado criterio de sistematicidad se ve también amagado por la regulación nuevamente en otra ley de las hipótesis de falsificación de tarjetas de crédito o débito y de uso de tarjetas falsificadas. Se trata de la Ley 20.009 que contempla un tipo con cinco alternativas en su art. $5^{\circ}$ : la falsificación de tarjetas de crédito o débito (a); distintas formas de uso de tarjetas falsificadas o sustraídas (b); la negociación, en cualquier forma, con estas tarjetas (c); distintas formas de uso ilícito de los datos o números de una tarjeta de crédito o débito (d); la negociación, en cualquier forma, con estos datos o números (e); el uso malicioso de una tarjeta bloqueada, en cualquier de las formas descritas precedentemente (f) ${ }^{13}$. En particular, las tarjetas de débito son expresión del proceso de desmaterialización del dinero, en la medida en que sustituyen a la moneda y al billete como medios de funcionamiento del dinero ${ }^{14}$. Las tarjetas de crédito cumplen también la función de pago, aunque en el marco de un sistema tripartito entre el titular de la tarjeta, el banco emisor y la institución financiera que otorga el crédito. Ambas clases de tarjetas vuelven ampliamente prescindible el uso de las monedas y de los billetes en las transacciones económicas. En la medida en que estas tarjetas se consideren equivalentes funcionales del dinero, su regulación en una ley separada tanto del Código penal como de la misma Ley orgánica del Banco Central, vuelve interna y externamente asistemática la legislación penal en la materia.

En este ámbito de consideraciones y, ahora explícitamente, en una perspectiva teleológica, cabe preguntarse por el fin de protección de la norma del art. $5^{\circ}$ de la Ley 20.009. Al contrario de lo que sugiere Hernández, no parece tratarse de una norma cuyo fundamento radique en la protección del patrimonio de una persona ${ }^{15}$. Ya la configuración del "perjuicio a terceros" como regla de calificación de la pena en el inciso tercero, cuestión que por cierto no se le escapa al autor mencionado, habla en el sentido de que el injusto descrito en el tipo base no deriva de la afectación del patrimonio. Además, la hipótesis de uso de una tarjeta bloqueada, prevista en el art. $5^{\circ}$ letra f), puede ser cometida principalmente por el propio titular de la tarjeta, lo cual descarta que se trate de la protección del patrimonio del tarjetahabiente. Este ciertamente puede resultar perjudicado por la realización de las otras conductas descritas en el tipo, pero esta circunstancia no lo erige necesariamente en titular del bien jurídico protegido por la norma. El art. $2^{\circ}$ de la ley establece las hipótesis en las que el tarjetahabiente puede bloquear las tarjetas, por lo que resulta lógico pensar que la alternativa típica del art. $5^{\circ}$ letra f) procura sancionar penalmente el abuso que este sujeto puede cometer en ese caso.

No obstante, es la hipótesis de uso prevista en el art. $5^{\circ}$ letra b) la que parece entregar un criterio para esclarecer este aspecto, ya que, a diferencia de las hipótesis de falsificación y,

\footnotetext{
${ }^{13}$ HERNÁNDEZ, Héctor, "Uso indebido de tarjetas falsificadas o sustraídas y de sus claves", Polit. crim. $\mathrm{N}^{\circ}$ 1 (2008), A2-5, pp. 26 y ss. en http://www.politicacriminal.cl/n_05/A_2_5.pdf

${ }^{14}$ Cfr. KÖHLER: "Humes Dilemma", cit. nota ${ }^{\circ} 12$, p. 888.

${ }^{15}$ HERNÁNDEZ, "Uso indebido de tarjetas”, cit. nota $n^{\circ} 13$, p. 35 y s.; nota ${ }^{\circ} 93$.
} 
ROJAS, Luis Emilio. "Modelos de regulación de los delitos de falsedad y de los delitos patrimoniales".

desde luego, de negociación, se sitúa claramente en el ámbito propiamente lesivo del bien jurídico, por lo que sirve, precisamente al encontrarse más cerca de la afectación al bien jurídico, para su clarificación. En dicha alternativa típica, la conducta prohibida radica en "usar, vender, exportar, importar o distribuir tarjetas de crédito o débito falsificadas o sustraídas", en una expresión sintética, circular tarjetas previamente falsificadas o sustraídas. Nótese que esta última referencia a la sustracción de una tarjeta de débito o crédito deslinda este ámbito fáctico del modelo de regulación de la falsedad documental, puesto que, a diferencia de éste, no es determinante la falsedad como tal. Lo relevante parece ser más bien la función que cumplen estas tarjetas en el tráfico económico como equivalentes funcionales del dinero. La lesión al bien jurídico se produce por la circulación de tarjetas de débito o crédito falsificadas o sustraídas, de un modo independiente de la eventual afectación a los derechos patrimoniales del tarjetahabiente o de la institución financiera emisora. En relación a ese momento de lesión, la propia hipótesis de falsificación del art. $5^{\circ}$ letra a) y, sobre todo, la de negociación en cualquier forma prevista en la letra c) del mismo artículo, representan formas anticipadas de criminalización, que ya han sido objeto de crítica ${ }^{16}$.

Esta disquisición teleológica ofrece un criterio para una delimitación internamente sistemática entre, por una parte, normas cuyo fundamento radica en la protección de intereses colectivos y, por otra, normas cuyo fin se acota a la protección de derechos patrimoniales, esto es, intereses básicamente personales. Aunque no estuviera todavía articulada en estos términos, esta distinción era muy clara para el legislador del siglo XIX. Esta claridad se expresa en las normas de los artículos 171, 179 y $184 \mathrm{CPCh}$, que regulan la hipótesis en que la falsificación de moneda, título o sello es tan grosera y ostensible que cualquiera puede darse cuenta a simple vista. La falsificación burda, por ejemplo, de una moneda, alcanza solamente relevancia individual y es punible, en consecuencia, en la medida en que se configuren los elementos propios del delito de estafa, tal como lo ordenan las disposiciones citadas. Es decir, estas reglas funcionan como un mecanismo que excluye esta hipótesis fáctica del ámbito de los delitos contra la fe pública y la reenvía al grupo de las estafas y otros engaños - arts. 467 y ss. CPCh -, esto es, delitos contra los derechos patrimoniales de la persona. De lo anterior se sigue que la falsificación de dinero, para que alcance relevancia colectiva, debe ser sutil en el sentido de asemejarse al dinero verdadero $^{17}$. Solamente en la medida en que la falsificación del dinero sea apta para hacer que éste circule en el tráfico económico, puede verse amagado un interés colectivo en su protección. De lo contrario, es decir, si cualquiera puede darse cuenta y así detener su circulación, pero no obstante una persona incurre en el error de creer que es verdadero y resulta perjudicada, entonces la relevancia del hecho se agota en su dimensión individual.

\subsection{Regulación vigente de las falsedades documentales.}

En el mismo sentido, la legislación penal aún vigente delimita de forma internamente sistemática la regulación de las falsedades documentales y de certificados en los arts. 193 y ss., por una parte, del grupo de las estafas y otros engaños en los arts. 467 y ss. CPCh, por

\footnotetext{
${ }^{16}$ HERNÁNDEZ, "Uso indebido de tarjetas", cit. nota n ${ }^{\circ} 13$, p. 31 y s.

${ }^{17}$ RIVACOBA, Manuel, "Objeto jurídico y sujeto pasivo de la falsificación de monedas", Gaceta Jurídica, $\mathrm{N}^{\circ} 70$ (1986), p. 8.
} 
Polít. crim. Vol. 12, № 23 (Julio 2017), Art. 10, pp. 380-408.

[http://www.politicacriminal.cl/Vol_12/n_23/Vol12N23A10.pdf]

otra. Es decir, para el legislador del siglo XIX era también muy claro que las falsedades documentales y de certificados vulneran intereses colectivos, por lo que se agrupan bajo el título IV sobre "delitos contra la fe pública" a inmediata continuación de la falsificación de monedas, títulos y sellos del Estado. Mientras que las estafas y otros engaños se insertan en el título IX sobre "delitos contra la propiedad", un derecho individual por antonomasia. Sin embargo, la doctrina imperante clasifica la falsificación de documentos privados tipificada en el art. 197 CPCh como una forma especial de estafa, esto es, un delito patrimonial, básicamente porque el texto de dicha norma exige un "perjuicio de tercero"18. Dicha doctrina interpreta este elemento en el sentido de un "perjuicio patrimonial" y, por ende, la norma tendría como fin la protección del patrimonio. El mencionado elemento ha tenido un efecto fuertemente distorsionador en la forma de comprender este delito, ya que ésta soslaya la relevancia del interés jurídico protegido por la norma básica de prohibición de la falsedad documental. No tiene mayor sentido ver en esta disposición una forma especial de estafa, que se agregaría a la ya innecesariamente casuística regulación de las estafas en los arts. 467, 468, 469, 470 y 473 CPCh. Aquí la doctrina es internamente asistemática, no la legislación penal.

Por otra parte, la técnica legislativa adoptada en el art. 193 CPCh para la descripción de la documentación falsa cometida por un empleado público en el cargo, ha condicionado una lectura de esta norma que releva en demasía el significado de la infracción de deberes funcionarios, en desmedro del injusto que deriva de la falsedad misma. Esta forma de regulación es hereditaria de una tradición jurídica que se remonta al Code Pénal de 1810 y que ha condicionado en la doctrina nacional, mas no en la doctrina francesa ni en la española, una lectura de las normas que soslaya y confunde los intereses jurídicos protegidos $^{19}$. Particularmente distorsionadora es la técnica adoptada en el art. $193 \mathrm{CPCh}$, pues, además de ser sumamente casuística, describe modalidades de comisión que incumben a la autenticidad del documento público (v.gr.: art. 193 N. 1 y N. 2) y otras que atañen a la verdad del mismo (art. 193 N. 4 CPCh) ${ }^{20}$. Lo anterior, todo en la misma norma del art. $193 \mathrm{CPCh}$, que, entonces, confunde la protección de dos intereses diversos entre sí, cuales son, por un lado, el interés en la protección de la autenticidad del documento público $\mathrm{y}$, por el otro, la protección de la verdad de hechos constatados en la documentación pública. Por ende, este tipo evidencia una inconsistencia teleológica interna.

Este defecto de la regulación vigente afecta gravemente la capacidad comunicativa de la norma. Un criterio fundamental que debe observarse en la formulación de tipos penales radica precisamente en asegurar dicha capacidad comunicativa, esto es, que el mensaje para

\footnotetext{
${ }^{18}$ Crítico ROJAS, Luis Emilio, "Deconstrucción del modelo dominante de comprensión de los delitos de falsedad documental", Polít. crim. Vol. 9, $\mathrm{N}^{\mathrm{o}} 18$ (2014), Art. 6, pp. 481 y ss., en http://www.politicacriminal.cl/Vol_09/n_18/Vol9N18A6.pdf ; también, MAYER, Laura, "La falsificación de instrumentos privados: ¿una estafa especial?”, Revista de Derecho UACh, vol. XXVII, No 2 (2014), pp. 224 y ss.

${ }^{19}$ ROJAS, Luis Emilio, "Dogmengeschichte der Urkundenfälschung“, en: FREUND, Georg; MURMANN, Uwe; BLOY, René; PERRON, Walter (editores), Grundlagen und Dogmatik des gesamten Strafrechtssystems. Festschrift für Wolfgang Frisch zum 70. Geburtstag, Berlin: Duncker \& Humblot, 2013, pp. 932 y ss.

${ }^{20}$ Cfr. PEÑA CERECEDA, Federico, "Observaciones acerca del artículo 27 de la Ley 4.808 sobre Registro Civil, de 31 de enero de 1930", Revista de Derecho y Jurisprudencia, Tomo 52, № 1 (1955), pp. 53 y ss.
} 
ROJAS, Luis Emilio. "Modelos de regulación de los delitos de falsedad y de los delitos patrimoniales".

el destinatario de la norma sea claro y unívoco, de tal modo que ésta pueda cumplir efectivamente su función orientadora y así redunde en la protección de bienes jurídicos ${ }^{21}$. Pues bien, el mensaje que actualmente emana de la norma del art. $193 \mathrm{CPCh}$ es confuso y equívoco. Primero, por la formulación sumamente casuística del tipo, que describe ocho (8) modalidades distintas de cometer falsedad. Esta forma de descripción genera la impresión de que lo prohibido es la realización de cada modalidad de comisión, cuando lo punible es la falsedad cometida en el documento. Segundo, porque la norma prohíbe en definitiva crear un documento público inauténtico y, al mismo tiempo, un documento público que "falta a la verdad en la narración sobre un hecho sustancial" (art. 193 N. 4).

Esta formulación defectuosa del tipo se ve agravada en la norma del art. 194 CPCh, que castiga al particular que comete falsedad en un documento público, puesto que este tipo se remite al precedente para la descripción del hecho punible. Esta remisión indistinta de la norma del art. 194 al tipo del art. 193 CPCh ha gatillado una discusión bastante estéril en la doctrina nacional, que discurre sobre la base de entender que esa remisión abarcaría solamente aquellas modalidades de comisión que atañen a la autenticidad del documento público, pero que excluiría a las modalidades de "falsedad ideológica", porque, así reza la argumentación estándar, "no existe un deber general de decir verdad". El problema básico de este argumento no radica en su enunciación, que en general puede compartirse, sino en que debe esclarecer los casos especiales en que sí existiría tal deber para los particulares. Esto, la doctrina nacional no lo esclarece y cuando ofrece una argumentación, lo hace de una manera muy confusa.

\subsection{Regulación de los delitos patrimoniales.}

La actual regulación de esta clase de delitos en el título IX sobre "delitos contra la propiedad" observa dos criterios básicos de clasificación. Por una parte, deslinda la regulación de los delitos contra la propiedad en sentido estricto - arts. 432 y ss. - de las defraudaciones y estafas - arts. 466 y ss. CPCh -, concebidas modernamente como delitos patrimoniales. Por otra parte, al interior de los delitos contra la propiedad en sentido estricto, diferencia aquellos que se cometen por apropiación de los delitos de destrucciónarts. 474 y ss. CPCh.

Ahora bien, en cuanto a la regulación de las defraudaciones y estafas, esto es, de los delitos patrimoniales, la legislación penal vigente evidencia algunos problemas de orden sistemático interno. Un primer problema dice relación con la defectuosa tipificación de los delitos patrimoniales que se cometen en el marco de relaciones de confianza previa entre autor y víctima. En particular, constituye un problema la inserción del tipo de apropiación indebida en el art. 470 N. 1 CPCh entre las estafas y no en el grupo de los delitos contra la propiedad en sentido estricto. A este problema sistemático, se le suma un vacío patente en la legislación penal, que surge de la ausencia de un tipo general de administración desleal ${ }^{22}$. Este vacío ha constreñido a la praxis jurisprudencial a elegir entre dos estrategias alternativas para enfrentar las hipótesis fácticas de esta forma grave de ataque al patrimonio

\footnotetext{
${ }^{21}$ OSSANDÓN, La formulación de los tipos penales, cit. nota ${ }^{\circ}$ 9, pp. 275 y ss.

${ }^{22}$ Cfr. HERNÁNDEZ, Héctor, "La administración desleal en el Derecho penal chileno", Revista de Derecho de la PUC de Valparaíso, vol. XXVI, semestre I (2005), pp. 203 y ss.
} 
Polít. crim. Vol. 12, No 23 (Julio 2017), Art. 10, pp. 380-408.

[http://www.politicacriminal.cl/Vol_12/n_23/Vol12N23A10.pdf]

ajeno, cuales son, primero, recurrir al tipo de estafa del art. $468 \mathrm{CPCh}$ o, segundo, extender el alcance del tipo de apropiación indebida en la modalidad de "distracción de dineros".

Ambas vías alternativas de interpretación terminan por distorsionar el alcance del sistema de los delitos contra la propiedad y el patrimonio, tal como fue concebido por el propio legislador del siglo XIX. La primera línea de interpretación devela una profunda incomprensión de la diferencia básica entre la forma de ataque al patrimonio ajeno propia de la estafa, que en general presupone la inexistencia de una relación de confianza previa, y el modo de agresión al mismo bien jurídico característico de la administración desleal, que presupone necesariamente una relación de confianza formulada en un deber de tutela patrimonial que vincula previamente al autor. Esta incomprensión se explica nuevamente por la falta de un tipo general de administración desleal, que impide siquiera realizar este sencillo ejercicio de comparación con el tipo de estafa.

En la segunda línea interpretativa, la praxis ha contado con cierto respaldo de la doctrina, que ha desarrollado una teoría de la doble naturaleza del tipo del art. $470 \mathrm{~N}$. $1 \mathrm{CPCh}$, buscando delimitar y restringir el ámbito de aplicación de esta norma ${ }^{23}$. Según esta teoría, subyacen a este mismo tipo dos normas de naturaleza distinta, una que deriva de la modalidad de apropiación indebida de cosas muebles, cuyo fin radicaría en la protección de la propiedad frente a actos de disposición vedados al sujeto que tiene dichas cosas bajo un título de tenencia fiduciaria. Y otra norma que derivaría de la modalidad de "distracción de dineros" u otras cosas fungibles, cuyo fin no podría radicar en la protección de la propiedad, puesto que la entrega de estas cosas por parte del dueño en virtud de un título de tenencia fiduciaria al sujeto que luego sería eventualmente autor, transferiría el dominio sobre dichas cosas por el carácter fungible de éstas. Nadie puede "apropiarse de lo propio", ergo, esta teoría plantea que el fin de la norma radica no en la protección de la propiedad, sino que del patrimonio ajeno y que el injusto de esta modalidad sería el característico de la administración desleal. Por consiguiente, según este planteamiento, el delito se consuma en esta modalidad al provocarse un perjuicio patrimonial a otro.

Esta solución doctrinaria desnaturaliza la norma e introduce un quiebre lógico interno al tipo del art. 470 N. 1 CPCh. El texto de la ley menciona como objeto principal sobre el que recae la conducta de apropiación o de distracción precisamente al dinero, por lo que es dable pensar que justamente esa hipótesis fáctica es la que se tenía en mente en el momento de formular la norma. Además, al mencionar "cualquiera otra cosa mueble" como otro objeto posible sobre el que pueden recaer ambas conductas, la ley penal aquí, a diferencia que en el art. $432 \mathrm{CPCh}$ sobre delito de hurto, prescinde del requisito de ajenidad. Por consiguiente, aun cuando se parta de la premisa que las normas de Derecho civil contemplan la mentada transferencia del dominio por la entrega de cosas fungibles en virtud de títulos de la clase mencionada -cuestión que resulta bastante dudosa-, no existe necesidad de interpretar esta norma al menos en clave de accesoriedad estricta a las normas de Derecho civil.

\footnotetext{
${ }^{23}$ HERNÁNDEZ, "La administración desleal”, cit. nota n 22, pp. 228 y ss.; BASCUÑ̃́N, Antonio, "Delitos contra intereses instrumentales", Revista de Derecho Universidad Adolfo Ibáñez, Santiago: (2004), p. 340 y s.
} 
ROJAS, Luis Emilio. "Modelos de regulación de los delitos de falsedad y de los delitos patrimoniales".

Esas constataciones de texto hablan más bien en el sentido de una concepción monista de la norma, no dualista de la misma. La tesis de la doble naturaleza reconstruye dogmáticamente la norma en términos que afectan su capacidad comunicativa, puesto que de su texto fluye simplemente como mensaje la prohibición de apropiarse o distraer dineros $\mathrm{u}$ otras cosas muebles recibidos en virtud de un título de tenencia fiduciaria. Mientras que la lectura propuesta por esa solución doctrinaria obliga a relacionar de manera invertida los elementos del texto, de tal forma que lo prohibido sería apropiarse solamente de cosas muebles y distraer solamente dineros recibidos en virtud de dicha clase de títulos. Con otras palabras, en vez de una sola prohibición subyacente al tipo, se derivarían en esta lectura dos prohibiciones distintas, una de apropiarse indebidamente de lo ajeno y otra de provocar un perjuicio al patrimonio de otro.

Por último, respecto de la regulación vigente de las estafas, cabe observar que ésta adolece de una técnica legislativa sumamente casuística, que contraviene flagrantemente el criterio básico de economía legislativa. El legislador del siglo XIX ha erigido en tipos separados distintas hipótesis de estafa en los arts. 467 y ss. CPCh, donde pueden destacarse el tipo de estafa sobre las cosas a entregar en virtud de un título obligatorio (art. 467), la hipótesis en que el engaño recae más bien sobre determinados atributos de la persona del autor (art. 468), la norma casuística del art. 469 que incluye algunas hipótesis basadas en relaciones de confianza previa (v.gr.: art. 469 N. 3 y N. 4), la norma del art. 470 CPCh que, además de incluir el ya mencionado tipo de apropiación indebida (art. 470 N. 1) y una hipótesis de administración desleal del capitán de buque en relación a esta nave (art. 470 N. 2), contempla una serie de hipótesis especiales de estafa (art. 470 N. 3 - 7), y, finalmente, la norma de clausura del art. $473 \mathrm{CPCh}$, que castiga al que "defraudare o perjudicare a otro usando de cualquier engaño que no se halle expresado en los artículos anteriores". De esta última norma, es posible colegir la intención del legislador decimonónico de criminalizar cualquier hipótesis de estafa considerada relevante en esa época, lo cual puede explicar la técnica engorrosa y sumamente casuística adoptada en la formulación de los tipos.

El legislador moderno ha sido fiel a esa intención, acentuando de esta manera los defectos de la legislación penal decimonónica. En esta dirección, ha incorporado en el art. 470 N. 8 una hipótesis de estafa en el marco de prestaciones unilaterales del Estado, cuya consumación se determina en el momento en que un sujeto obtiene fraudulentamente del Estado u otro organismo público una "prestación improcedente". La formulación de este tipo, si bien tiene el sentido de cubrir ciertas hipótesis fácticas del así denominado "fraude de subvenciones", devela un problema de sistemática interna, que deriva de su inserción en el marco de los delitos de estafa. Este radica en que impide desarrollar una dogmática acorde con la peculiaridad que se presenta en esta hipótesis y que se aparta de los otros casos de estafa, cual es, que aquélla se desenvuelve precisamente en el marco de prestaciones unilaterales, vale decir, que desde un principio no se encuentran dirigidas por el Estado a generar una igualación económica entre prestación y contraprestación. La premisa contraria es aquella que subyace en general al marco de relaciones en el que se cometen estafas, esto es, en el contexto de prestaciones bilaterales de prestación y contraprestación, en el cual rige la prohibición de engañar. La regulación vigente soslaya esta diferencia de contexto. 
Polít. crim. Vol. 12, No 23 (Julio 2017), Art. 10, pp. 380-408.

[http://www.politicacriminal.cl/Vol_12/n_23/Vol12N23A10.pdf]

Recientemente, el legislador penal ha innovado mediante la incorporación de una hipótesis de "fraude inmobiliario" en el art. 470 N. 9 CPCh y otra de "fraude de seguros" en el numeral 10 del mismo artículo. El tipo de "fraude inmobiliario" delimita el ámbito de aplicación de la norma mediante la descripción del sujeto activo, la que se restringe a personas dedicadas al rubro inmobiliario o de la construcción de bienes raíces destinados a la vivienda, locales comerciales u oficinas. Describe la conducta mediante los verbos "suscribir o hacer suscribir" un contrato de promesa de compraventa de bien inmueble, la que es típica en la medida en que se omiten las exigencias contempladas en el art. 138 bis de la Ley General de Urbanismo y Construcción (en adelante, LGU). Estas exigencias son, por una parte, de carácter formal y, por otra, obligan al otorgamiento de una garantía por parte del promitente vendedor. Como puede verse, la formulación de este tipo pierde relación con la estafa, pues la descripción de la conducta típica no contiene, al menos explícitamente, ninguna exigencia de engaño. El único nexo consiste en el requisito, formulado en la parte final de la disposición, de provocar "un perjuicio patrimonial para el promitente comprador" como consecuencia de la realización de la conducta sin cumplir las exigencias del art. 138 bis LGU. Este último requisito plantea una serie de problemas dogmáticos, como por ejemplo que tal perjuicio sólo puede configurarse en la forma de un peligro.

Pero, en la perspectiva de la técnica legislativa, la formulación y ubicación del tipo es desacertada. Porque genera la impresión de que se trata de una hipótesis especial de estafa, cuando lo relevante no es el engaño, sino la infracción a los deberes establecidos por el art. 138 bis LGU a quienes se dedican a este rubro. El legislador impone deberes al promitente vendedor en favor del promitente comprador y, por ende, parte de la premisa de la existencia de una relación asimétrica entre ambas partes. En este sentido, se trata acá de una hipótesis sui generis de administración desleal y, por ende, el tipo responde más bien a este modelo de regulación. Por otro lado, si dichos deberes eran los determinantes en la concepción del legislador, pareciera que, de compartirse la necesidad de contemplar un tipo de esta clase, resultaría más ajustado a un criterio de sistemática externa insertar esta norma en la propia LGU y no en el CPCh, por el efecto distorsionador que puede tener en la regulación de este último.

Finalmente, respecto de la hipótesis de "fraude de seguros" incorporada en el art. 470 N. 10 CPCh, cabe observar que, desde el punto de vista de la técnica legislativa, esta se asemeja a la adoptada en el art. 470 N. 8, pues la consumación se alcanza ya al "obtener" un pago indebido, sin que resulte aplicable el principio del saldo ni compensación alguna, ambos criterios determinantes de la comprobación del perjuicio patrimonial en el contexto de la dogmática del delito de estafa. Esta cierta anticipación del momento consumativo ya a la disposición patrimonial permite resolver los problemas que se plantean en el ámbito de esta clase de estafa con el principio de inmediatez. Pues, normalmente el pago de un seguro se produce como consecuencia de una serie de actos, que se activa con la información del siniestro por parte del asegurado y sigue con una cadena de conductas que incluye la intervención relevante de terceros frente a las partes del contrato de seguro ${ }^{24}$. Sin embargo, la técnica legislativa adoptada en la descripción de la conducta típica se aparta parcialmente

\footnotetext{
${ }^{24}$ PIÑA, Juan Ignacio, Fraude de seguros. Cuestiones penales y de técnica legislativa, Santiago: Editorial Jurídica de Chile, 2006, pp. 91 y ss.
} 
ROJAS, Luis Emilio. "Modelos de regulación de los delitos de

falsedad y de los delitos patrimoniales".

del modelo tradicional de la estafa. Específicamente, la hipótesis de "provocar intencionalmente" un siniestro y la de "ocultar la cosa asegurada", no pueden reconducirse sin más al concepto de engaño propio de este delito.

\section{Comparación del Código penal español y del Strafgesetzbuch.}

\subsection{Tipos modelo del Código penal español de 1995.}

Dado que los modelos de regulación son, por un lado, más abstractos que los tipos positivos de la parte especial y, por otro, más concretos que los tipos delictivos elaborados en la parte general, según Vogel la elaboración de modelos se realiza mediante la crítica al Derecho positivo y, sobre todo, por medio de la comparación de la legislaciones penales ${ }^{25}$. Una vez que se ha valorado críticamente la legislación penal vigente en la materia respectiva, procede ahora compararla con otra forma de regulación, cual es la contenida en el Código penal español de 1995.

Desde el punto de vista de la técnica legislativa, en general la regulación de la materia en el CPE 1995, modificado recientemente por la Ley Orgánica 1, de 30 de marzo de 2015, representa un significativo avance ${ }^{26}$. Satisface plenamente el criterio de economía legislativa, pues a partir de una legislación penal farragosa, como la del antiguo Código penal de 1848 incluso con sus reformas posteriores, se ha reducido en número los tipos penales y, además, éstos aparecen formulados de manera muy sintética, lo cual favorece la capacidad comunicativa de las normas ${ }^{27}$. En cuanto al criterio sistemático, la legislación penal moderna ordena los tipos penales según la distinción entre la protección de bienes jurídicos individuales y colectivos, empezando con las normas penales que brindan protección a la primera clase de intereses. En la materia, este criterio implica que se invierte el orden de la antigua legislación penal y se ubican los tipos que contemplan los delitos patrimoniales en el grupo de los delitos contra bienes jurídicos individuales - v.gr.: art. 248 (estafa), art. 253 (apropiación indebida) -, mientras que las falsedades se encuentran entre los delitos contra bienes jurídicos colectivos - arts. 386 y ss. CPE.

En este último ámbito, cabe destacar el tipo del art. 386 CPE sobre falsificación de monedas, en cuyo numeral $1^{\circ}$ contempla la hipótesis de alteración o fabricación de moneda falsa y en los numerales $2^{\circ}$ y $3^{\circ}$, así como en sus incisos $2^{\circ}$ y $3^{\circ}$, castiga diversas formas de usar el dinero falso ${ }^{28}$. El art. $387 \mathrm{CPE}$ establece el alcance del concepto de moneda, el cual abarca la metálica y el "papel moneda de curso legal" así como la moneda de otros países de la Unión Europea y la extranjera ${ }^{29}$. A continuación, el art. 389 CPE español somete bajo pena la falsificación y el uso de sellos de Correos o de efectos timbrados.

\footnotetext{
${ }^{25}$ VOGEL, "Wirtschaftskorruption", cit. nota n 6, p. 398.

${ }^{26}$ Cabe tener presente la modificación significativa al Código penal español de 1995 introducida por la reciente Ley Orgánica 1, de 30 de marzo de 2015, que, como se indica a continuación, también introduce algunos cambios en los delitos tratados aquí.

${ }^{27}$ OSSANDÓN, La formulación de los tipos penales, cit. nota ${ }^{\circ}$ 9, pp. 275 y ss.

${ }^{28}$ La Ley Orgánica 1/2015 introduce una modificación en el numeral $3^{\circ}$, en orden a prescindir de la exigencia previa de connivencia con el falsificador, siendo ahora suficiente que el autor conozca la falsedad.

${ }^{29}$ La Ley Orgánica 1/2015 introduce un nuevo inciso $2^{\circ}$ al art. 387, que considera también falsa la moneda que se fabrica en instalaciones y con materiales legales, pero sin autorización de la autoridad competente.
} 
Polít. crim. Vol. 12, № 23 (Julio 2017), Art. 10, pp. 380-408.

[http://www.politicacriminal.cl/Vol_12/n_23/Vol12N23A10.pdf]

En comparación con la legislación penal aún vigente en Chile, esta forma de regulación es legislativamente más económica y sistemática. En el mismo tipo del art. 386 CPE se reúnen la figura de falsificación de monedas y las principales formas de hacer uso de moneda falsa. En una perspectiva sistemática, resulta acertada la disposición del art. 387 CPE que establece como equivalente, para los efectos de la aplicación de esta norma, la moneda metálica y el papel moneda de curso legal, ya que ambas no son más que formas de expresión de la misma institución del dinero. No interesa la protección del objeto moneda o billete, sino que la protección del dinero mediante la protección de las monedas y de los billetes.

Desde este mismo punto de vista, cabe hacer notar que en este acápite del CPE no se incluye un tipo de falsificación de tarjetas de crédito o débito, sino que se criminaliza solamente la hipótesis de uso indebido de dichas tarjetas o de sus datos en perjuicio de su titular o de un tercero en el art. 248 apdo. 2 letra c) CPE sobre delito de estafa. Esta decisión sistemática del legislador español implica que estas tarjetas no merecen protección como equivalentes funcionales del dinero, sino que solamente en el marco de la protección del patrimonio. En consecuencia, el modelo de regulación acogido por el CPE en este punto puede llamarse modelo patrimonial.

En materia de falsedades documentales, la regulación del CPE significa un claro avance desde el punto de vista de la técnica legislativa, pues en el art. 390 se logra una síntesis de lo que antiguamente se describía en una serie de modalidades de comisión de la falsedad. Básicamente, el art. $390 \mathrm{CPE}$ reúne en los numerales $1^{\circ}$ a $3^{\circ}$ hipótesis que atañen a la protección de la autenticidad del documento, mientras que en el numeral $4^{\circ}$ se conserva la hipótesis paradigmática de "falsedad ideológica", en cuyo texto se alude expresamente a la "verdad en la narración de los hechos". Es interesante hacer notar que el texto se refiere simplemente al "documento" y no a una clase determinada del mismo, lo cual hace pensar que esta norma se concibe como un tipo básico en este grupo de delitos. Recién a partir del art. $392 \mathrm{CPE}$, norma que castiga al particular que comete en "documento público, oficial o mercantil" alguna de las falsedades descritas en los tres primeros números del Art. 390, se colige que esta última disposición se refiere a esta clase de documentos como objeto de la conducta típica. Por otra parte, el tipo del art. 390 CPE sufre una restricción en el marco de la descripción del sujeto activo del delito, pues éste es solamente "la autoridad o funcionario público que, en el ejercicio de sus funciones, cometa falsedad". En este aspecto, el CPE mantiene la técnica legislativa del Code Pénal de 1810 en el sentido de anteponer sistemáticamente, en el grupo de los delitos de falsedad documental, el tipo de falsedad cometida por un funcionario público.

Esta opción sistemática sigue condicionando la forma de interpretar las normas y de comprender estos delitos. Así, por ejemplo, en un comentario a esta norma del CPE, se señala que existen dos clases de falsedades: 
ROJAS, Luis Emilio. "Modelos de regulación de los delitos de falsedad y de los delitos patrimoniales".

"las falsedades materiales suponen una intervención material del autor en el soporte del documento, que provoca una falta de correspondencia entre la declaración contenida en el documento y su autor, y la creación de una prueba documental inauténtica. Las falsedades ideológicas atentan contra la veracidad de los documentos, provocando una falta de correspondencia entre lo que se declara y lo que figura en el documento. El documento resultante constituye una prueba documental auténtica, pero falsa" ${ }^{\text {"30 }}$.

Sin embargo, a renglón seguido en el mismo comentario, se sostiene que "se trata, en todas sus modalidades, de un delito especial consistente en la infracción de deberes de veracidad, del que solo puede ser autor la autoridad o funcionario público" 31 . Como puede verse, la relevancia que adquiere la descripción del sujeto activo en su condición de funcionario público es tal que, teleológicamente, se termina por soslayar la diferencia de los intereses protegidos en esta misma norma -autenticidad y verdad del documento. La calidad de funcionario público produce un efecto unificador de la norma que perpetúa esa confusión de intereses, la que a su turno impide darse cuenta que crear un documento inauténtico y crear un documento auténtico pero no verdadero, son dos cuestiones diferentes. En este sentido, el modelo de regulación, que este tipo consagra, puede denominarse modelo funcionarial.

El art. 392 CPE regula la hipótesis en que un particular comete "en documento público, oficial o mercantil, alguna de las falsedades descritas en los tres primeros números del apdo. 1 del artículo 390”. En cuanto al objeto de la conducta típica, esta norma equipara valorativamente el documento mercantil al documento público u oficial, lo cual no es más que un resabio de la técnica adoptada ya en el Code Pénal de 1810 - arts. 145 y ss. A diferencia que en el documento público u oficial, en el otorgamiento de un documento mercantil no interviene necesariamente ningún funcionario público, de modo que su tratamiento equivalente no parece justificarse.

Respecto del sujeto activo del delito, el art. 392 CPE restringe la punibilidad de la falsedad cometida por un particular en estas clases de documento solamente a las tres primeras alternativas típicas del art. 390, excluyendo de este ámbito a la modalidad de "falsedad ideológica" prevista en el numeral $4^{\circ}$ de esta última disposición. Esta decisión legislativa cuenta con el respaldo de la doctrina española ${ }^{32}$. Sin embargo, esta exclusión que se justifica cuando se trata de un documento mercantil, no parece serlo igualmente respecto de un documento público, por ejemplo, en el caso en que un particular miente sobre el hecho del nacimiento de una persona frente al oficial de registro civil encargado de extender la partida de nacimiento basada en esta información. ¿Qué argumento podría justificar materialmente la impunidad de la conducta del particular en este caso? Este caso y otras hipótesis fácticas similares podrían resolverse acudiendo a las normas sobre autoría y participación, pero solamente al costo de recurrir a imbricadas categorías como la del "instrumento cualificado no doloso" o, al invocar la regla de inducción - art. 28 apdo. 2 a), concediendo "excepciones" al principio de accesoriedad limitada. Los problemas que se

\footnotetext{
${ }^{30}$ CORCOY, Mirentxu; MIR, Santiago, Comentarios al Código penal. Reforma LO 5/2010, Valencia: Tirant lo Blanch, 2011, p. 860.

${ }^{31}$ CORCOY/MIR, Comentarios, cit. nota ${ }^{\circ} 30$, p. 860. (cursiva añadida).

${ }^{32}$ Así, OLAIZOLA, Inés, “Artículo 392”, en: COBO DEL ROSAL, Manuel; MORILLAS CUEVA, Lorenzo (directores), Comentarios al Código penal. Segunda época, t. XII, Madrid: Dykinson, 2011, pp. 233 y ss.
} 
Polít. crim. Vol. 12, No 23 (Julio 2017), Art. 10, pp. 380-408.

[http://www.politicacriminal.cl/Vol_12/n_23/Vol12N23A10.pdf]

plantean en el marco de este tipo derivan, entonces, de la remisión al modelo de regulación funcionarial que consagra el art. 390 CPE.

La regulación del CPE en este acápite tiene la virtud de contemplar de modo separado los tipos de uso de documento falso en el art. 393, cuando se trata de documento público, oficial o mercantil, y en el art. 396, respecto del documento privado. En cuanto a este último, la falsedad cometida en esta clase de documento se encuentra prevista y sancionada en el art. $395 \mathrm{CPE}$, cuya descripción de la conducta se caracteriza por una remisión nuevamente a las tres primeras modalidades del art. 390 y por una restricción en el plano subjetivo mediante la incorporación de un elemento específico del tipo que aparece descrito con la frase "para perjudicar a otro". El problema que plantea este elemento es que también se encuentra configurado en los mismos términos como un elemento subjetivo específico en el tipo de uso del art. $396 \mathrm{CPE}^{33}$.

Sin embargo, la realización típica del uso de documento privado falso "para perjudicar a otro" presupone que se ha falsificado previamente el documento privado también "para perjudicar a otro". La solución del problema pasa por reconocer que se usa siempre un documento falso, por lo que el contenido de este elemento subjetivo específico no puede ser el mismo en el marco del tipo de falsedad, que se ubica claramente en un ámbito previo a la lesión del bien jurídico, que en el tipo de uso de documento falso, que ya se ubica en el ámbito lesivo y presupone así necesariamente la realización previa de la falsedad.

En el ámbito de los delitos patrimoniales, el CPE demuestra un notorio avance en la forma de su regulación. En primer término, el delito de estafa aparece consagrado en una fórmula sintética en el art. 248 apdo. 1, que exige la configuración de los cuatro elementos característicos de este delito según la dogmática de la estafa, vale decir, engaño "bastante", error de otro, "acto" de disposición patrimonial y perjuicio propio o ajeno. Naturalmente, la doctrina discute sobre el alcance del requisito de "bastante" del engaño y también puede provocar cierta discusión que el tipo exija expresamente un "acto" de disposición patrimonial, además del alcance que pueda tener la exigencia de perjuicio, según la teoría que se siga respecto del concepto de patrimonio. Nada que no pueda resolverse con el arsenal conceptual de la dogmática de los delitos patrimoniales.

En el apdo. 2 del mismo art. 248 CPE se establecen como delitos distintas formas de "fraude informático". En la letra a), se inserta una hipótesis de transferencia de cualquier "activo patrimonial" mediante manipulación informática o un artificio semejante, con lo cual se resuelven los problemas de subsunción de esta hipótesis en el tipo general de estafa o de hurto. En la letra b), se consagra un delito de preparación, consistente en la fabricación o circulación de programas informáticos destinados a ese fin delictivo. Y en la letra c), se encuentra prevista la hipótesis de uso indebido de tarjetas de crédito o débito, o de sus datos, en perjuicio de su titular o de un tercero, opción legislativa que parte de la premisa

\footnotetext{
${ }^{33}$ No se percatan de este problema ni PAREDES CASTAÑÓN, José Manuel, “Artículo 395”, en: COBOS DEL ROSAL/MORILLAS CUEVA, Comentarios, cit. nota ${ }^{\circ}$ 32, pp. 418 y ss., al comentar este elemento del tipo del art. 395 ni JERICÓ OJER, Leticia, "Artículo 396", en: COBOS DEL ROSAL/MORILLAS CUEVA, Comentarios, cit. nota ${ }^{\circ}$ 32, pp. 438 y ss., al comentar el mismo elemento en el tipo del art. 396 CP.
} 


\section{ROJAS, Luis Emilio. "Modelos de regulación de los delitos de}

falsedad y de los delitos patrimoniales".

del carácter netamente patrimonial de esta figura delictiva, vale decir, que suscribe un modelo patrimonial de regulación.

En este ámbito, el CPE presentaba un problema derivado de la defectuosa tipificación del delito de administración desleal en el art. 295. Este problema ha sido recientemente solucionado mediante la Ley Orgánica 1, de 30 de marzo de 2015. Dicho tipo se insertaba entre los delitos societarios, decisión sistemática que generaba la impresión de que en la legislación penal el patrimonio social merece mayor protección que el patrimonio de cualquiera otra persona, por ejemplo, de una persona jurídica de Derecho público o de una persona natural. El CPE de 1995 seguía, entonces, un modelo societario del delito de administración desleal. Esta limitación se salvaba parcialmente con el amplio alcance que la jurisprudencia y parte de la doctrina le daban al tipo de apropiación indebida antes contemplado en el art. $252 \mathrm{CPE}$, en la modalidad de distracción de "dinero, efectos, valores o cualquiera otra cosa mueble o activo patrimonial" recibido en depósito, comisión o administración. Según la teoría de la doble naturaleza de esta norma, en dicha hipótesis se trataba de la administración desleal del patrimonio de una persona distinta de una sociedad $^{34}$.

El problema mencionado ha sido resuelto por la Ley Orgánica 1/2015 mediante la supresión del art. 295, la incorporación de un tipo general de administración desleal en el art. 252 y la reubicación del tipo de apropiación indebida en el art. 253 del CPE, cuyo texto ahora excluye la discutida hipótesis de "distracción de dineros". Con esta nueva regulación de la materia, quedan definitivamente claras las diferencias sobre todo en los presupuestos normativos de ambos tipos, que la tesis de la doble naturaleza tendía a difuminar. El tipo de apropiación indebida exige un título de tenencia fiduciaria, que "produzca la obligación" de entregar o devolver los objetos recibidos, esto es, que funda un deber cuyo contenido se acota a esta obligación. En cambio, un tipo de administración desleal presupone la existencia de un deber de lealtad, cuyo contenido radica en la obligación general de cuidar el patrimonio ajeno y confiado al administrador. El alcance de este deber es mucho mayor y depende básicamente del ámbito en el cual se gestiona el patrimonio, por ejemplo, si se trata del patrimonio de una persona natural, dicha administración se somete a las reglas del Derecho civil y a los límites definidos contractualmente, mientras que de tratarse del patrimonio de una sociedad, su gestión se somete a las reglas y principios del Derecho de sociedades. En la medida en que los límites de la gestión del patrimonio ajeno vienen fijados por normas de Derecho privado, el tipo de administración desleal se vuelve estructuralmente accesorio a estas normas para la configuración del injusto.

Sin perjuicio de lo anterior, la forma en que se acuña el nuevo tipo de administración desleal ahora en el propio art. 252 del CPE, origina alguna duda sobre el alcance que se le pretende dar a la norma. El texto reza de la siguiente forma: "Serán punibles con las penas

\footnotetext{
${ }^{34}$ Por todos, BACIGALUPO, Enrique, Falsedad documental, estafa y administración desleal, Madrid: Marcial Pons, 2007, pp. 183 y ss., quien sostiene: "El art. 252 CP contiene dos tipos penales que, a su vez, protegen dos bienes jurídicos diferentes. El tipo de la apropiación indebida de cosas muebles, que protege el derecho de propiedad y el de distracción de dinero, que protege el patrimonio. Ambos deben ser considerados separadamente" (p. 183).
} 
Polít. crim. Vol. 12, No 23 (Julio 2017), Art. 10, pp. 380-408.

[http://www.politicacriminal.cl/Vol_12/n_23/Vol12N23A10.pdf]

del artículo 249 o, en su caso, con las del artículo 250, los que teniendo facultades para administrar un patrimonio ajeno, emanadas de la ley, encomendadas por la autoridad o asumidas mediante un negocio jurídico, las infrinjan excediéndose en el ejercicio de las mismas y, de esa manera, causen un perjuicio al patrimonio administrado". Pareciera que el legislador español incorpora un tipo de administración desleal restringido a la modalidad de abuso, en el sentido acuñado en la doctrina y jurisprudencia sobre el $\S 266$ del Código penal alemán, con exclusión de la modalidad de mera deslealtad - vid. infra 2.2. En efecto, dos notas de este nuevo tipo hablan en esta dirección. Primero, la referencia a las facultades de administración sobre el patrimonio ajeno, que son características del presupuesto del tipo de abuso. Segundo, la descripción de la conducta prohibida en los términos de una infracción no meramente de un deber de lealtad, sino que "excediéndose en el ejercicio" de las facultades de administración, es decir, mediante abuso de las mismas. Más allá de esta discusión, lo claro es que el CPE, con esta reforma, ha abandonado definitivamente el modelo societario del tipo de administración desleal.

\subsection{Tipos modelo del Strafgesetzbuch.}

En el ámbito de la falsificación de dinero, la regulación del Strafgesetzbuch en los $\S \S 146$ y ss., en general, se caracteriza por satisfacer los criterios de economía legislativa y de sistematicidad. Desde un punto de vista sistemático, el StGB, a diferencia del CPE, inserta estos parágrafos entre los delitos contra intereses colectivos antes de los delitos contra bienes jurídicos individuales. El § 146 I apdo. 1 StGB contempla el tipo de falsificación de dinero. Por dinero se entiende un determinado medio de pago emitido por el Estado o por una institución facultada por éste como portador de valor y para su circulación en el tráfico público, sin consideración de la obligación general de recibirlo ${ }^{35}$. En el mismo $§ 146$ I StGB, se contemplan las hipótesis de procurarse de dinero falso, en el apdo. 2, y de circular el mismo en el tráfico, en el apdo. 3. De modo subsidiario a esta última disposición, se contempla un tipo separado de circulación de dinero falso en el $\S 147$ StGB. En el $\S 148$ StGB se somete bajo pena la falsificación de sellos del Estado o de otra autoridad de Derecho público, que sirven de marca o signo de un determinado valor monetario y gozan de fe pública, mientras que en el $\S 149$ StGB se establece un delito de preparación de la falsificación de dinero y de sellos. En el $\S 151$ StGB se listan los títulos de valor ("Wertpapiere") equivalentes al dinero para los efectos de la aplicación de las normas precedentes.

El legislador alemán sigue la opción sistemática de incorporar los tipos de falsificación de tarjetas de pago ("Zahlungskarten") en los $\S \S 152$ a y 152 b StGB a continuación de las normas sobre falsificación de dinero y de títulos de valor equivalentes. Esta decisión sistemática parece acertada, pues, en la medida en que estas tarjetas cumplen una función sustitutiva del dinero efectivo ("Bargeld") en el tráfico económico, merecen un tratamiento penal independiente de las normas de protección al patrimonio ${ }^{36}$. En el $\S 152$ a StGB, la norma protege las tarjetas de pago emitidas por instituciones bancarias o financieras que sirven como tarjetas de débito ("Bargeldkarten"), con independencia del crédito otorgado al

\footnotetext{
35 SCHÖNKE, Adolf; SCHRÖDER, Horst; STERNBERG-LIEBEN, Detlev, Strafgesetzbuch. Kommentar, $29^{\mathrm{a}}$ ed., München: C.H. Beck, 2014, § 146, nm. 2.

${ }^{36}$ SCHÖNKE/SCHRÖDER/STERNBERG-LIEBEN, Strafgesetzbuch, cit. nota ${ }^{\circ} 35, \S 152$ a, nm. 1.
} 
ROJAS, Luis Emilio. "Modelos de regulación de los delitos de falsedad y de los delitos patrimoniales".

tarjetahabiente ${ }^{37}$. Esta misma norma protege al cheque y a la letra de cambio ("Wechsel") frente a la falsificación. El $§ 152$ a IV contiene una definición de tarjetas de pago para estos efectos. En cambio, en el $\S 152$ b StGB la norma protege las tarjetas de pago con función de garantía, esto es, aquellas que posibilitan un pago garantizado en el sistema tripartito ("Drei-Parteien-System"), fundamentalmente las tarjetas de crédito ${ }^{38}$. El $\S 152$ b IV StGB contiene una definición de estas tarjetas para los efectos de la aplicación de esta norma. Es decir, en relación a las tarjetas de pago, los tipos de los $\S \S 152$ a y 152 b StGB consagran lo que puede denominarse un modelo monetario, mas no patrimonial.

En materia de falsedades documentales, cabe destacar que éstas se insertan sistemáticamente a continuación de los delitos patrimoniales en los $\S \S 267$ y ss. StGB. Esta opción sistemática permite una interpretación de estas normas en clave liberal, vale decir, en el sentido de la protección de la información correcta como presupuesto básico para el ejercicio de los derechos patrimoniales y otros derechos de la persona ${ }^{39}$. Sin embargo, el tipo de falsa documentación en el cargo se encuentra inserto entre los delitos funcionarios ("Amtsdelikte") en el $\S 348$ StGB. Desde una perspectiva sistemática interna, esta decisión del legislador alemán parece desacertada. Primero, porque esta ubicación hace perder de vista su relación con el tipo de falsa documentación mediata del $\S 271$ StGB. El § 271y el $\S$ 348 son dos caras de la misma moneda, puesto que ambas normas se dirigen a proteger conjuntamente la verdad de la documentación pública y los registros públicos ${ }^{40}$. La única diferencia radica en que la primera norma protege este interés frente a la falsedad provocada por cualquier ciudadano, mientras que la segunda lo hace solamente frente a la cometida por un funcionario público. Segundo, porque esta ubicación sistemática del $\S 348$ StGB genera la impresión de que lo injusto de este delito consiste fundamentalmente en la infracción de deberes funcionarios. Pero, ésta no constituye el núcleo del injusto, sino que éste deriva más bien de la información falsamente documentada o registrada por el empleado público. En este sentido, pareciera que el $\S 348$ StGB consagra un tipo híbrido, esto es, que fluye de dos modelos distintos de regulación. Por un lado, el modelo funcionarial que se sigue de su ubicación sistemática. Y, por otro, el que puede denominarse un modelo falsario, que se deduce de la forma en que la conducta prohibida se encuentra tipificada.

Ahora bien, también en una perspectiva sistemática, el StGB tiene la virtud de anteponer al interior de este grupo de delitos el tipo básico de falsedad documental en el $\S 267$, cuya norma indudablemente se dirige a la protección de la autenticidad del documento. Ya la antigua versión de esta norma en el Reichsstrafgesetzbuch hacía explícito que se trataba aquí de la protección de la autenticidad de un documento público o de un documento privado, "relevante para la prueba de relaciones jurídicas" ${ }^{41}$.Esta decisión sistemática ahorra las tribulaciones que provoca la confusión de la protección de la autenticidad y de la

\footnotetext{
${ }^{37}$ SCHÖNKE/SCHRÖDER/STERNBERG-LIEBEN, Strafgesetzbuch, cit. nota n $35, \S 152$ a, nm. 3.

${ }^{38}$ SCHÖNKE/SCHRÖDER/STERNBERG-LIEBEN, Strafgesetzbuch, cit. nota $n^{\circ} 35, \S 152$ b, nm. 2.

${ }^{39}$ En este sentido, JAKOBS, Urkundenfälschung, cit. nota $\mathrm{n}^{\circ}$ 4, pp. 11 y ss.; PUPPE, en: KINDHÄUSER, Urs; NEUMANN, Ulfrid; PAEFFGEN, Hans-Ullrich, Nomos Komentar Strafgesetzbuch, $4^{\text {a }}$ ed. 2013, § 267, nm. 6 y ss.

${ }^{40}$ PUPPE, cit. nota ${ }^{\circ} 39, \S 271, \mathrm{~nm} .3$ y ss.

${ }^{41}$ Cfr. ROJAS, "Dogmengeschichte", cit. nota n 19, pp. 944 y ss.
} 
Polít. crim. Vol. 12, No 23 (Julio 2017), Art. 10, pp. 380-408.

[http://www.politicacriminal.cl/Vol_12/n_23/Vol12N23A10.pdf]

verdad del documento público en la misma norma del art. 193 CPCh y del art. 390 CPE a la doctrina chilena y española, respectivamente. Para la doctrina alemana resulta claro que la norma del $\S 267 \mathrm{StGB}$, por un lado, protege la autenticidad del documento y que, por otro lado, las normas de los $\S \S 271,348$ StGB protegen el contenido de verdad en documentos públicos ${ }^{42}$.

Sin embargo, este mismo origen histórico en el Reichsstrafgesetzbuch es la fuente de un quiebre lógico interno que evidencia el tipo del $\S 267$ StGB. Originalmente, esta norma consagraba un delito de dos actos, lo cual implicaba que, para realizar completamente el tipo, era menester falsificar un documento y, además, usarlo. No obstante, el mismo tipo diferenciaba en el plano subjetivo la clase de intención con la cual se realizaba uno y otro acto, pues la falsedad se debía realizar con una "intención antijurídica", mientras que el uso del documento falso debía cometerse para el "engaño en el tráfico jurídico". Recién mediante la reforma legislativa en la época nacionalsocialista el tipo alcanzó su formulación actual ${ }^{43}$. Ahora, las modalidades del hacer un documento falso y de falsificar un documento auténtico se contemplan de modo alternativo a la modalidad típica de hacer uso del documento falso, pero todas deben realizarse con la intención de "engaño en el tráfico jurídico". Por eso, la doctrina califica este tipo como una suerte de delito de emprendimiento, porque las modalidades de falsedad, que se ubican en el ámbito previo a la lesión del bien jurídico, se someten a la misma pena que la modalidad de hacer uso de un documento falso, que se sitúa ya en el ámbito propiamente lesivo del bien jurídico ${ }^{44}$. El acertijo que plantea esta forma de regulación dice relación con el alcance que se le debe dar al elemento de intención de "engaño en el tráfico jurídico", en el sentido de si debe tener el mismo contenido en ambas clases de modalidad o si debe diferenciarse su alcance, según si se trate de las modalidades de falsedad, por una parte, o de la modalidad de hacer uso, por otra. Dicho acertijo no ha podido ser resuelto aún ni por la doctrina ni por la jurisprudencia.

En el ámbito de los delitos patrimoniales, el tipo general de estafa se encuentra previsto y sancionado en el $\S 263$ StGB. Junto a este delito, el StGB ofrece una profusa regulación de estafas especiales, comenzando con la estafa informática en el $\S 263$ a y la obtención fraudulenta de prestaciones en el $\S 265$ a, la estafa de subvenciones en el $\S 264$, la estafa en la colocación de capitales en el $\S 264$ a, la estafa de créditos en el $\S 265$ b, la colusión en licitaciones en el $\S 298$ y el fraude se seguros en el $\S 265$. Esta proliferación de "estafas especiales" se explica por la voluntad político-criminal de cubrir hipótesis fácticas en las cuales fallaba la configuración de alguno de los elementos del tipo general de estafa del $\S$ 263 StGB, ya sea que se tratase del error, como en el "fraude informático", o porque no se alcanzaba a configurar la disposición patrimonial perjudicial, como en la estafa de subvenciones o de créditos.

Finalmente, el StGB distingue claramente entre el tipo básico de apropiación indebida en el $\S 246$, ubicado entre los delitos contra la propiedad, y el tipo general de administración

\footnotetext{
${ }^{42}$ Así, ARZT, Günther; WEBER, Ulrich; HEINRICH, Bernd; HILGENDORF, Eric, Strafrecht. Besonderer Teil, $2^{\mathrm{a}}$ ed., Bielefeld: Verlag Ernst und Werner Gieseking, 2009, § 33 nm. 1.

${ }^{43}$ VORMBAUM, Moritz, "Das Handeln ,zur Täuschung im Rechtsverkehr'. Zur Auslegung des § 267 I StGB”, Goltdammer's Archiv für Strafrecht, número 3 (2011), p. 172 y s.

${ }^{44}$ PUPPE, cit. nota ${ }^{\circ} 39, \S 267, \mathrm{~nm} .99$.
} 
ROJAS, Luis Emilio. "Modelos de regulación de los delitos de falsedad y de los delitos patrimoniales".

desleal del $\S 266$ StGB, situado entre los delitos patrimoniales. El primer tipo mencionado cumple una función ancla en el sistema de los delitos contra la propiedad, pues su norma castiga la apropiación antijurídica de una cosa ajena, sin que constituya un presupuesto que el autor tenga la cosa previamente bajo su custodia, sino que, cuando existe tal relación de confianza, se agrava la pena en el $\S 246$ II StGB ${ }^{45}$. Esta configuración típica del delito de apropiación indebida se distancia nítidamente tanto del tipo previsto en el art. $470 \mathrm{~N}$. 1 CPCh como del mismo tipo contemplado en el art. 253 CPE.

Por su parte, en el $\S 266$ StGB se contempla un tipo general de administración desleal, que resulta de la formulación sintética del tipo de abuso ("Missbrauchstatbestand") y del tipo de deslealtad o quiebre de confianza ("Treubruchstatbestand") ${ }^{46}$. Este segundo tipo ha sido históricamente criticado por su amplitud, pues en la práctica basta con verificar la existencia de un deber de tutela patrimonial y la provocación de un perjuicio mediante su infracción para que el delito se configure. El tipo de deslealtad cumple la función de cubrir las hipótesis fácticas que no quedan abarcadas por el tipo de abuso. Este último es más restringido, pues presupone la existencia de facultades de disposición sobre el patrimonio ajeno, cuyo ejercicio abusivo que se traduce en una relación externa jurídicamente eficaz, pero internamente excesiva, fundamenta suficientemente la punibilidad del hecho. No obstante, la formulación sintética de ambas figuras en un mismo tipo implica la exigencia de un deber de tutela y de un perjuicio patrimonial, entendido mayoritariamente en sentido económico, tanto en la modalidad de abuso como en la de deslealtad. Dichas exigencias restrictivas son plausibles respecto del tipo de deslealtad, mas no se justifican respecto del tipo de abuso, cuyo alcance ya es en sí mismo restringido. La formulación sintética de ambas figuras en un mismo tipo genera esta inconsistencia lógica interna al $\S 266 \mathrm{StGB}^{47}$. Junto a este tipo se contemplan la figura de administración desleal de cotizaciones previsionales en el $\S 266$ a y un tipo de abuso de tarjetas de cheque y de tarjetas de crédito en el $\S 266$ b StGB.

\section{Valoración crítica del Anteproyecto de 2005 y del Proyecto de Código penal de 2014; comentario al Anteproyecto de 2015.}

\subsection{El Anteproyecto de Código penal chileno de diciembre de 2005.}

El ACP 2005 parece seguir la sistemática del CPE, lo cual explica que las falsedades se encuentren tipificadas en los arts. 234 y ss. entre los delitos contra intereses colectivos, después de los delitos contra bienes jurídicos individuales, entre los cuales se insertan los delitos patrimoniales en los arts. 159 y ss.

Respecto de la falsificación de dinero, cabe destacar que el ACP 2005 sigue acá la sistemática del StGB, pues contempla un tipo de falsificación de dinero en el art. 234 y, a inmediata continuación, un tipo de falsificación de títulos de valor y tarjetas de pago en el

\footnotetext{
${ }^{45}$ ARZT/WEBER/HEINRICH/HILGENDORF, Strafrecht. $B T$, cit. nota n ${ }^{\circ} 42, \S 15 \mathrm{~nm} .9$ y ss., nm. 35 y ss.

${ }^{46}$ ARZT/WEBER/HEINRICH/HILGENDORF, Strafrecht. BT, cit. nota n ${ }^{\circ} 42, \S 22 \mathrm{~nm} .4$ y ss.

47 A cuya solución Nelles dedicó su tesis de habilitación, en: NELLES, Ursula, Untreue zum Nachteil von Gesellschaften, Berlin: Duncker \& Humblot, 1991, pp. 209 y ss., pp. 504 y ss.
} 
Polít. crim. Vol. 12, No 23 (Julio 2017), Art. 10, pp. 380-408.

[http://www.politicacriminal.cl/Vol_12/n_23/Vol12N23A10.pdf]

art. 235. En cuanto a la técnica legislativa adoptada en la formulación del tipo del art. 234, esta responde al criterio de economía legislativa, ya que reúne en una misma norma la hipótesis de falsificación de moneda y la de circularla en el tráfico económico. Además, declara equivalente la moneda metálica y el billete de papel moneda de curso legal, en Chile o en el extranjero, en el inciso $2^{\circ}$ del art. 234 ACP 2005. No obstante, falsificar dinero es una conducta con un significado antijurídico diferente que circular dinero falso, por lo que parece aconsejable tipificar ambas conductas por separado, a fin de maximizar la capacidad comunicativa de las normas. En cuanto al tipo del art. 235, desde un punto de vista sistemático interno su formulación reafirma la idea que los títulos de valor y las tarjetas de pago cumplen una función equivalente al dinero en el tráfico económico, lo cual aparece relevado en el texto de la norma al señalar " $u$ otros documentos o dispositivos empleados como medio de pago equivalente a la moneda". La diferencia radica básicamente en que el dinero y los títulos de valor son en sí mismos portadores de valor, no así las tarjetas de débito o de crédito, que comparten con aquellos solamente su condición de medios de pago con poder liberatorio. Es decir, el ACP 2005 sigue aquí un modelo monetario de regulación.

En materia de falsedades documentales, el ACP 2005 sigue la sistemática del CPE, pues empieza con las hipótesis de falsedades cometidas en documentos y registros públicos, documentos oficiales y certificados, en los arts. 238 a 242, y relega a una figura de carácter residual la hipótesis de falsificación de documento privado en los arts. 243 y 244. Esta opción sistemática interna no trasluce claramente la diferenciación básica entre una norma de protección a la autenticidad del documento y normas de protección a la verdad de la documentación pública. En cuanto a la formulación de los tipos en particular, esta distingue entre las falsedades cometidas en documentos públicos y en inscripciones en registros públicos en los arts. 238 y 239, por una parte, y las falsedades cometidas en documentos oficiales y certificados en los arts. 240 y 241, por otra. Asimismo, respecto de los tipos de falsedad cometida en documentos públicos y en inscripciones en registros públicos, diferencia entre la hipótesis de delito común en el art. 238 y el delito especial cometido por funcionario público en el art. 239.

En cuanto a la distinción entre documentos y registros públicos y documentos oficiales, no resulta claro que se justifique un tratamiento diferenciado, si en ambos casos se pretende proteger la verdad de la documentación pública. Si lo que se pretende es más bien excluir del ámbito de la punibilidad la falsificación de simples documentos administrativos o de tales documentos con un contenido puramente dispositivo, entonces este criterio debería quedar más bien entregado a la doctrina y jurisprudencia. De lo contrario, no se observa una diferencia esencial entre un documento público y un documento oficial, que da constancia fehaciente de un hecho jurídicamente relevante. Respecto de la distinción de sujetos, esta parece adecuada y particularmente correcta resulta empezar con el tipo que describe el delito común y luego insertar el delito especial, puesto que de este modo se pone de relieve que lo determinante en este grupo de delitos es la falsedad cometida y que la eventual infracción de deberes funcionarios sólo cumple un rol secundario con un efecto agravante de la pena. En este sentido, el ACP 2005 parece acoger un modelo falsario y no funcionarial en estos tipos. A nivel de descripción de la conducta típica, resulta un tanto engorrosa la forma todavía bastante casuística de formulación de una serie de modalidades 
ROJAS, Luis Emilio. "Modelos de regulación de los delitos de falsedad y de los delitos patrimoniales".

de comisión. Resultaría conforme a una técnica respetuosa del criterio de economía legislativa una formulación más sintética de descripción de la conducta típica, que redunde en una mayor capacidad comunicativa de las normas subyacentes a cada tipo.

En este orden de consideraciones, la formulación del tipo de falsificación de documento privado en el art. 243 ACP 2005 resulta desacertada. Primero, porque no se formula ningún elemento a partir del cual pueda colegirse claramente que aquí sólo puede tratarse de la protección de la autenticidad del documento. Segundo, porque, al contrario, la mantención de la referencia al "perjuicio de tercero" en los mimos términos del actual art. 197 CPCh no hace más que perpetuar la creencia equivocada de que aquí se está en presencia de una forma especial de estafa, es decir, de un delito patrimonial ${ }^{48}$. Aquí el ACP 2005 queda anclado en un modelo patrimonial de este tipo. Tercero, porque la descripción de la conducta típica mediante el verbo "forjar" en todo o en parte un documento parece enderezada a solucionar un problema puramente aparente, cual es el de la supuesta no punibilidad de la hipótesis de "forjamiento" de un documento íntegramente falso. El origen de este problema aparente se remonta a una modificación introducida al Código penal español a mediados del siglo XX, que introdujo expresamente como una modalidad de comisión de la falsedad la hipótesis de forjamiento íntegro del documento falso. Como la misma modificación no se había introducido al art. $193 \mathrm{CPCh}$, parte de la doctrina y jurisprudencia nacional dedujo de esta omisión legislativa la impunidad de esta hipótesis, lo cual resulta un contrasentido que ya había sido advertido por Antonio Quintano Ripollés en España, pues no se concibe la falsificación de un todo sin la de sus partes ${ }^{49}$. Por eso, este autor declaraba redundante la introducción de tal modalidad de comisión. En efecto, si lo punible es cometer falsedad en un documento, resulta absurdo considerar punible la falsificación parcial y no así la falsedad total de un documento. Cuarto, porque regula en el mismo inciso $1^{\circ}$ del art. 243 la falsedad de documento privado y la hipótesis de hacer uso del documento falso, forma de tipificación que podría generar el mismo dilema que provoca la regulación conjunta de ambas modalidades en el apdo. 1 del $§ 267$ StGB.

En el ámbito de los delitos patrimoniales, el tipo del delito de estafa en el art. 159 se destaca por su formulación sintética, que supera la antigua tipificación basada en la descripción de una serie de modalidades de comisión en el art. $468 \mathrm{CPCh}$. A renglón seguido, en el art. 160 se incluye una hipótesis de "fraude informático" consistente básicamente en un desplazamiento patrimonial producido mediante intervención en un sistema de tratamiento automatizado de información o de los datos contenidos en el mismo.

Por último, se formula un tipo general de administración desleal en el art. 161 ACP 2005, mediante el cual se colma el vacío de punibilidad que deja el actual art. 470 N. 1 CPCh. En este sentido, el ACP 2005 se aparta del modelo societario que antes subyacía al tipo del art. 295 CPE. No obstante, en comparación con el $\S 266$ StGB, la formulación del tipo del art. 161 opta básicamente por acotarse al tipo de abuso del parágrafo citado del StGB, excluyendo el tipo de simple deslealtad, lo cual relegaría a la impunidad una serie de hipótesis fácticas que no quedan abarcadas por el siempre restrictivo tipo de abuso.

\footnotetext{
${ }^{48}$ Termina de desmantelar esta creencia MAYER, "La falsificación", cit. nota n 18, pp. 224 y ss.

${ }^{49}$ QUINTANO RIPOLLÉS, Antonio, La falsedad documental, Madrid: Instituto Editorial Reus, 1952, p. 187 y s.
} 
Polít. crim. Vol. 12, No 23 (Julio 2017), Art. 10, pp. 380-408.

[http://www.politicacriminal.cl/Vol_12/n_23/Vol12N23A10.pdf]

Fundamentalmente, se trata de hipótesis de infracción grave al deber de tutela patrimonial que no se comete mediante el abuso de facultades de disposición, sencillamente porque el autor no se encuentra dotado formalmente de tales facultades, por ejemplo, la decisión conscientemente perjudicial para el patrimonio social adoptada por los miembros del directorio de una sociedad anónima.

\subsection{El Proyecto de Código penal chileno de marzo 2014.}

En general, el proyecto de Código penal chileno presentado al Congreso Nacional en marzo de 2014 se destaca por una técnica legislativa claramente más sintética ${ }^{50}$. En el ámbito de las falsedades, el PCP 2014 toma la misma decisión sistemática del CPE y del ACP 2005 en orden a insertar los tipos de falsedad entre los delitos contra intereses colectivos, después de los delitos que atentan contra bienes jurídicos individuales. En el art. 395 se formula de manera sintética el tipo de falsificación de dinero. Sin embargo, a diferencia del ACP 2005 y de la técnica legislativa del StGB, el PCP 2014 opta por insertar un tipo de uso indebido de tarjetas de débito o de crédito en el art. 334, a continuación de los tipos de estafa y fraude informático. Subyace a esta decisión sistemática una concepción patrimonial de este ilícito, que de hecho se traduce en la exigencia de perjuicio en el tipo básico del art. 334 inc. $1^{\circ}$ PCP 2014. En este sentido, el PCP 2014 suscribe un modelo patrimonial de este tipo.

En materia de falsedades documentales, el PCP 2014 mantiene el orden sistemático del ACP 2005, en el sentido de anteponer el tipo de falsificación en documento público en el art. 397. Este tipo describe el delito común de falsedad en esta clase de documento, sin embargo, con el uso del verbo "forjar", la forma de redacción se expone a la misma crítica formulada precedentemente. El tipo del art. 398 describe el delito especial de falsedad en documento público, con una formulación claramente más sintética que la propuesta en el ACP 2005. Esta forma de regulación conjunta se aparta decididamente del modelo funcionarial subyacente al art. $193 \mathrm{CPCh}$. En el art. 400, se contempla la hipótesis de falsificación en documento privado, que sufre una restricción en el plano subjetivo con la exigencia del elemento "para engañar en el tráfico jurídico y perjudicar a otro en la adquisición, goce o ejercicio de sus derechos". La exigencia conjunta de ambos elementos subjetivos parece redundante, puesto que ya el engaño en el tráfico jurídico resulta perjudicial para los derechos de otro, en la medida en que se induce a éste a un error sobre la existencia de un documento. También en este art. 400 se describe la conducta típica con el verbo "forjar", que parece ser una mala traducción del verbo "herstellen" ocupado en el apdo. 1 del $§ 267$ StGB.

En materia de delitos patrimoniales, el PCP 2014 incluye las figuras centrales de esta clase de ilícitos. Sin embargo, en la formulación concreta de cada tipo, es posible constatar algunos detalles que podrían generar algunos problemas en la aplicación de las normas. En este orden de consideraciones, la formulación del tipo del delito de estafa en el art. 330 parece excesivamente detallista en su redacción. Así, menciona expresamente junto a la

\footnotetext{
${ }^{50}$ Es preciso aclarar que el autor de la presente contribución participó en la formulación de esta parte del proyecto, de modo que las líneas siguientes deben ser entendidas en gran parte como un ejercicio de autocrítica.
} 
ROJAS, Luis Emilio. "Modelos de regulación de los delitos de falsedad y de los delitos patrimoniales".

provocación de error mediante engaño "o lo mantuviere en el error", aparentemente para despejar las dudas sobre la punibilidad de la comisión de estafa mediante omisión. Asimismo, explicita en demasía el alcance del requisito de disposición patrimonial con la oración "induciéndolo a hacer, omitir o tolerar algo que importe una disposición patrimonial", con lo cual se pretende también despejar las dudas en torno a una disposición patrimonial realizada pasivamente. A continuación del delito de estafa, se inserta una hipótesis de "fraude informático" con desplazamiento patrimonial en el art. 333 y el ya mencionado uso indebido de tarjetas de débito o de crédito en el art. 334.

Por último, el PCP 2014 se destaca también por incluir un tipo general de administración desleal en el art. 336. En este sentido, el PCP 2014 se aparta también del modelo societario del anteriormente vigente art. $295 \mathrm{CPE}$. Sin embargo, en la formulación del texto se advierte una cierta indecisión en torno a consagrar el tipo de abuso y el tipo de mera deslealtad, puesto que ambos se redactan de modo copulativo en el inciso $1^{\circ}$, con la oración siguiente: "el que, teniendo a su cargo la gestión de intereses patrimoniales de otro en virtud de ley, orden de la autoridad o convención y abusando de sus facultades, le irrogare perjuicio". Precisamente, existen hipótesis fácticas graves de administración desleal mediante una gestión infiel de los intereses patrimoniales ajenos, sin abuso de facultades, simplemente porque frecuentemente la víctima no le ha concedido dichas atribuciones al eventual autor del delito. Sin perjuicio de este detalle, la formulación del PCP 2014 parece ser más completa que el mismo tipo incluido en el ACP 2005.

\subsection{Comentario final al Anteproyecto de 2015.}

Desde el punto de vista de la técnica legislativa, el Anteproyecto de 2015 se mantiene en la misma línea de una formulación sintética de los tipos penales en materia de falsedades. Así, el tipo de falsificación de dinero, contemplado en el art. 357, conserva prácticamente el mismo tenor que su precedente del PCP 2014. Respecto de la hipótesis de uso indebido de una tarjeta de crédito o débito, esta se contempla como una modalidad especial del "fraude informático" en el art. 297 ACP 2015, numeral 3. Sin embargo, esta misma hipótesis se restringe al uso no autorizado de los "datos codificados" en tales tarjetas. A continuación, en el art. 298 ACP 2015, se tipifican diversas hipótesis de preparación de los ilícitos constitutivos de "fraude informático". El ACP 2015 mantiene aquí un modelo patrimonial de esa clase de ilícitos.

En el ámbito de las falsedades documentales, el ACP 2015 introduce un cambio sistemático relevante al anteponer un tipo general de falsificación de documentos en el art. 358, que hace expresa referencia al carácter inauténtico del documento falsificado, con lo cual clarifica el fin de protección de esta norma en orden a proteger solamente la autenticidad del documento. De este modo, se deslinda claramente el interés en la protección de la autenticidad del documento de aquel existente en la protección de la verdad del mismo. Sin embargo, al interior de este tipo básico, dicha hipótesis de falsificación se tipifica, en su inciso $1^{\circ}$, respecto del documento público y luego, en el inciso $2^{\circ}$, respecto de "un documento de cualquiera otra índole". Este orden interno del precepto no es coherente con la decisión sistemática de anteponer el tipo básico de falsedad documental, realizable en cualquier documento, de modo que dicho orden es atribuible todavía a un último estertor de 
Polít. crim. Vol. 12, No 23 (Julio 2017), Art. 10, pp. 380-408.

[http://www.politicacriminal.cl/Vol_12/n_23/Vol12N23A10.pdf]

la sistemática del Code Pénal de 1810. Respecto del tipo de falsedad cometida al otorgarse un documento público, "faltando a la verdad al dar fe sobre hechos y circunstancias", es decir, cuya norma protege la verdad de la documentación pública, cabe observar una diferencia de fondo, en comparación tanto con el ACP 2005 como con el PCP 2014. Esta norma, contemplada en el art. 359 ACP 2015, resulta aplicable solamente al funcionario público que comete tal clase de falsedad, mas no al particular que realiza la misma conducta al otorgarse un documento público, al formarse un registro o libro público o al practicarse una inscripción. En el inciso $2^{\circ}$ del mismo precepto, se castiga a cualquiera que hiciere uso del documento público previamente falsificado. Es decir, la norma opta por castigar al particular solamente como autor del uso del documento público falso, pero no por cometer la falsedad misma. En consecuencia, la hipótesis en que un particular interviene en el otorgamiento de un documento público falso, sin luego hacer uso del mismo, queda regida por las reglas generales sobre autoría y participación, específicamente por la regla contemplada al efecto en el art. 30 inciso $3^{\circ}$ del ACP 2015. Pero entonces, el tipo del art. 359 ACP 2015 parte de la premisa que el particular no se encuentra obligado a la verdad, ni aún en el contexto de otorgamiento de un documento público, es decir, de una premisa contraria a la que subyace a los tipos del art. 238 ACP 2005 y del art. 398 PCP 2014.

Finalmente, en materia de delitos patrimoniales, se mantiene prácticamente la misma formulación del tipo del delito de estafa en el art. 296 ACP 2015, salvo un tratamiento diferente de la hipótesis en que la persona que incurre en el error es poco cauta o diligente. A diferencia de la regla del art. 330 del PCP 2014, que en ese caso contemplaba una rebaja del marco penal, ahora el precepto mencionado del ACP 2015 declara que esta circunstancia personal no obsta a la configuración del engaño típico. En cuanto al tipo de administración desleal, contemplado en el art. 302 del ACP 2015, cabe señalar que la indecisión en torno a la regulación conjunta de la modalidad de abuso y de mera deslealtad, que se detecta en el art. 336 del PCP 2014, se resuelve claramente en el sentido de tipificar ambas modalidades de manera alternativa, siguiendo en este punto abiertamente el modelo del Código penal alemán.

\section{Conclusiones: comparación de modelos de regulación.}

Vogel sostiene que los modelos de regulación son valorativamente neutrales, porque su coherencia lógica, sistemática y teleológica interna no garantiza que sean compatibles con normas de orden constitucional y con los principios reconocidos de política criminal, como el de ultima ratio, los criterios de merecimiento y necesidad penal o el principio de protección de bienes jurídicos en su faz trascendental ${ }^{51}$. Esta neutralidad valorativa permite proceder a una comparación de los modelos de regulación eminentemente descriptiva, sin la pretensión de agotar los problemas de legitimación material que cada tipo modelo puede abrir.

\footnotetext{
${ }^{51}$ VOGEL, "Wirtschaftskorruption", cit. nota n ${ }^{\circ}$ 6, p. 410 y s.
} 
ROJAS, Luis Emilio. "Modelos de regulación de los delitos de falsedad y de los delitos patrimoniales".

\subsection{Falsificación de dinero y tarjetas de pago.}

Respecto de la falsificación de dinero, evidentemente no puede regir otro modelo de regulación que el monetario. Este modelo es común a todas las legislaciones penales comparadas. Las diferencias aparecen en relación con las tarjetas de pago, básicamente de débito y de crédito. En este ámbito, es posible identificar dos modelos de regulación distintos. Por un lado, un modelo monetario, que es adoptado en los $\S \S 152$ a, 152 b del StGB y es seguido en el art. 235 del ACP 2005. Este modelo de regulación tiene la ventaja de reconocer que estas tarjetas cumplen efectivamente una función equivalente al dinero en la economía moderna. Pero desconoce que tales tarjetas, a diferencia de las monedas y los billetes, no son portadores de valor. Por otro lado, tanto el art. 248 apdo. 2 letra c) del CPE como el art. 334 del PCP 2014 y el art. 297 ACP 2015 suscriben un modelo patrimonial en relación a estas tarjetas. Probablemente a partir de dicha constatación, esto es, que estas tarjetas no son portadoras de valor, este modelo otorga relevancia constitutiva del injusto solamente al uso indebido de tales tarjetas o de sus datos, mas no a la falsificación misma.

\subsection{Falsedades documentales.}

El art. 390 CPE contiene un tipo híbrido, puesto que teleológicamente su norma se dirige a la protección tanto de la autenticidad como de la verdad del documento. No obstante, la relevancia que la doctrina le asigna a la condición de funcionario del sujeto activo del delito produce un efecto unificador, que implica suscribir un modelo funcionarial de regulación. Sistemáticamente, la regulación del StGB tiene la virtud de distinguir con claridad la norma de protección a la autenticidad del documento de las normas cuyo fin radica en la protección de la verdad de la documentación pública. No obstante, la ubicación del $§ 348$ StGB entre los delitos funcionarios torna a este parágrafo en un tipo híbrido, que se nutre tanto de un modelo funcionarial como de uno falsario de regulación. Tanto los arts. 238 y 239 ACP 2005 como los arts. 397 y 398 PCP 2014, así como el art. 359 ACP 2015 - con algunos matices -, abandonan definitivamente el modelo funcionarial de regulación y abrazan uno netamente falsario.

En cuanto a la falsificación de documento privado, el modelo patrimonial de regulación aún pervive en el art. $395 \mathrm{CPE}$, pero solamente en el plano subjetivo, como uno de los fines posibles de la falsificación. El art. 243 ACP 2005 suscribe todavía este modelo de regulación, mientras que éste ha sido definitivamente superado en el art. 400 PCP 2014 y en el art. 358 ACP 2015.

\subsection{Delitos patrimoniales.}

Respecto del delito de estafa, es obviamente común a las legislaciones comparadas un modelo patrimonial de regulación. Las diferencias aparecen respecto del delito de administración desleal. El art. 295 CPE consagraba un modelo societario de regulación de este delito, el cual generaba irresolubles problemas sistemáticos internos con el delito de apropiación indebida antes tipificado en el art. 252 CPE. Con la reforma introducida al CPE por la reciente Ley Orgánica 1/2015, dicho modelo ha sido definitivamente abandonado. El $\S 266$ StGB suscribe un modelo patrimonial puro de regulación, aunque evidencia un 
Polít. crim. Vol. 12, № 23 (Julio 2017), Art. 10, pp. 380-408.

[http://www.politicacriminal.cl/Vol_12/n_23/Vol12N23A10.pdf]

problema lógico interno derivado de la síntesis en una misma norma de dos tipos originalmente distintos. Tanto el art. 161 ACP 2005 como el art. 336 PCP 2014 y el art. 302 ACP 2015 se apartan nítidamente del modelo societario y suscriben un modelo patrimonial de regulación de la administración desleal. No obstante, ninguno, salvo el último precepto citado, logra resolver de modo adecuado la disonancia lógica interna que evidencia el tipo modelo del § 266 StGB. 
ROJAS, Luis Emilio. "Modelos de regulación de los delitos de falsedad y de los delitos patrimoniales".

\section{BIBLIOGRAFÍA}

ARZT, Gunther; WEBER, Ulrich; HEINRICH, Bernd; HILGENDORF, Eric (editores), Strafrecht. Besonderer Teil, $2^{\mathrm{a}}$ ed., Bielefeld: Verlag Ernst und Werner Gieseking, 2009.

BACIGALUPO, Enrique, Falsedad documental, estafa y administración desleal, Madrid: Marcial Pons, 2007.

BASCUÑÁN, Antonio, "Delitos contra intereses instrumentales", Revista de Derecho Universidad Adolfo Ibáñez, N 1 (2004), pp. 291-345.

COBO DEL ROSAL, Manuel; MORILLAS CUEVA, Lorenzo (directores), Comentarios al Código penal. Segunda época, t. XII, Madrid: Dykinson, 2011.

CORCOY, Mirentxu; MIR, Santiago, Comentarios al Código penal. Reforma LO 5/2010, Valencia: Tirant lo Blanch, 2011.

D’ORS, Álvaro, “Contribuciones a la historia del ,crimen falsi'”, en: VV.AA., Studi in onore di Edoardo Volterra, Milán: Giuffrè, 1969, vol. II, pp. 527-558.

FEUERBACH, Paul Johann Anselm, Lehrbuch des gemeinen in Deutschland gültigen peinlichen Rechts, Aalen: Scientia Verlag, 1986 (1847).

HERNÁNDEZ, Héctor, "Uso indebido de tarjetas falsificadas o sustraídas y de sus claves", Política criminal, $\mathrm{n}^{\mathrm{o}} 5$ (2008), pp. 1-37.

, "La administración desleal en el Derecho penal chileno", Revista de Derecho, XXVI semestre I (2005), pp. 201-258.

JAKOBS, Günther, Urkundenfälschung, Köln: Carl Heymanns Verlag, 2000.

KINDHÄUSER, Urs; NEUMANN, Ulfrid; PAEFFGEN, Hans-Ulrich, Strafgesetzbuch. Nomos Kommentar, $4^{\mathrm{a}}$ ed., Baden-Baden: Nomos, 2013.

KÖHLER, Michael, „Humes Dilemma - oder: Was ist Geld? ,Geldschöpfung` der Banken als Vermögensrechtsverletzung“, en: FREUND, Georg; MURMANN, Uwe; BLOY, René; PERRON, Walter, Grundlagen und Dogmatik des gesamten Strafrechtssystems. Festschrift für Wolfgang Frisch zum 70. Geburtstag, Berlin: Duncker \& Humblot, 2013, pp. 887-923.

MAYER, Laura, "La falsificación de instrumentos privados: ¿una estafa especial?”, Revista de Derecho, vol. XXVII nº 2 (2014), pp. 217-241.

MOMMSEN, Theodor, Römisches Strafrecht, Leipzig: Duncker \& Humblot, 1899.

NELLES, Ursula, Untreue zum Nachteil von Gesellschaften, Berlin: Duncker \& Humblot, 1991.

OSSANDÓN, Magdalena, La formulación de tipos penales. Valoración crítica de los instrumentos de técnica legislativa, Santiago: Editorial Jurídica de Chile, 2009.

PEÑA CERECEDA, Federico, "Observaciones acerca del artículo 27 de la Ley 4.808 sobre Registro Civil, de 31 de enero de 1930”, Revista de Derecho y Jurisprudencia, Tomo 52, $\mathrm{N}^{\circ} 1$ (1955), pp. 53-59.

PIÑA, Juan Ignacio, Fraude de seguros. Cuestiones penales y de técnica legislativa, Santiago: Editorial Jurídica de Chile, 2006.

QUINTANO RIPOLLÉS, Antonio, La falsedad documental, Madrid: Instituto Editorial Reus, 1952.

RIVACOBA, Manuel, "Objeto jurídico y sujeto pasivo de la falsificación de monedas", Gaceta Jurídica n 70 (1986), pp. 2-9. 
Polít. crim. Vol. 12, № 23 (Julio 2017), Art. 10, pp. 380-408.

[http://www.politicacriminal.cl/Vol_12/n_23/Vol12N23A10.pdf]

ROJAS, Luis Emilio,"Dogmengeschichte der Urkundenfälschung“, en: FREUND, Georg; MURMANN, Uwe; BLOY, René; PERRON, Walter (editores), Grundlagen und Dogmatik des gesamten Strafrechtssystems. Festschriftfür Wolfgang Frisch zum 70. Geburtstag, Berlin: Duncker \& Humblot, 2013, 925-947.

, "Deconstrucción del modelo dominante de comprensión de los delitos de falsedad documental”, Polít. crim. Vol. 9, No 18 (2014), Art. 6, pp. 477-520.

SCHÖNKE, Adolf; SCHRÖDER, Horst; STERNBERG-LIEBEN, Detlev, Strafgesetzbuch. Kommentar, $29^{\text {a }}$ ed., München: C.H. Beck, 2014.

VOGEL, Joachim, „Wirtschaftskorruption und Strafrecht - Ein Beitrag zu Regelungsmodellen im Wirtschaftsstrafrecht,- en: HEINRICH Bernd; HILGENDORF Eric; MITSCH, Wolfgang; STERNBERG-LIEBEN Detlev (editores), Festschrift für Ulrich Weber zum 70. Geburtstag, Bielefeld: Verlag Ernst und Werner Gieseking, 2004, pp. 395-411.

VORMBAUM, Moritz, „Das Handeln ,zur Täuschung im Rechtsverkehr“. Zur Auslegung des $§ 267$ I StGB““, Goltdammer’s Archiv für Strafrecht, 3 (2011), pp. 167-182. 